\title{
Measuring U.S. 19th Century Economic Activity Using Unexploited Railway and Postal Micro-level Data
}

\author{
Robert W. Dimand * \\ Brock University \\ Olivia Gong \\ Mcgill University \\ Michael O'reilly \\ Independent Researcher \\ Thomas Velk \\ McGill University \\ Mengyue Zhao \\ Mcgill And Oxford Universities \\ Data Collection at McGill University \\ EMILY SANDERS \\ JOHN STEWART \\ JONATHAN TAN YAN \\ ILANA WALTERS
}

\author{
HAYTHEM DRINE \\ MOLLY HARRIS \\ ALEXANDER ENGEL HERCZ \\ HANNAH LIDDLE
}

\begin{abstract}
For the past several years, we have presented and published studies based on postal related data, from postmaster cash books and the Official Register, where we use postmaster salary data as a measure of local, highly disaggregate proxies for general economic activity at town and village level. Using micro-level, high frequency, nationally uniform and previously unknown data, we will report on the outcome of measuring levels of economic activity, political influence and social mobility phenomena. In our latest work, we will use a recently published work of railroad history investments in the 19th century. The railroad history we have is highly detailed, naming particular towns and routes. Our own micro data will allow us to associate our postmaster data with railway town information at the
\end{abstract}

\footnotetext{
* Corresponding author: Robert W. Dimand, Department of Economics, Brock University, 1812 Sir Isaac Brock Way, St. Catharines, Ontario L2S 3A1, Canada; E-mail: rdimand@brocku.ca

(C) 2019 by Robert W. Dimand ,Terrence Hines ,Olivia Gong, Michael O'Reilly, Thomas Velk and Mengyue Zhao. Licensed under the Creative Commons Attribution - Noncommercial 3.0 Licence (http://creativecommons.org/licenses/by-nc/3.0/. Available http: //rofea.org.
} 
Review of Economic Analysis 12 (2020) 1-57

same micro level. Our data will also allow us to report the economic activity of nonrailway towns. We will then have, at the micro-level, bi-annual comparisons made over the life of the railway routes. The relative economic, political and demographic impact of railway investment will be examined. For example, as we have the names, birthplaces and ethnic origins of postmasters in addition to their salaries. We can measure not just differences in economic activity between railway and non-railway towns but even examine questions like: "Are the railway towns places where new immigrants get to be postmasters more quickly than elsewhere?" Our larger purpose is to advertise our ever-expanding postal based dataset, which provides information of interest to economists, sociologists, historians and political scientists.

Keywords: 19th century US economic activity, railways, postal data

JEL classifications: N11, N41, N71

\section{Introduction}

Previously little used official publications of the Post Office Department allow us to produce a local, highly disaggregate, picture of economic activity at the town and village level for the $19^{\text {th }}$ century United States. Such detailed local economic data has heretofore been unavailable for analysis. These data sources include the Official Register ${ }^{1}$ (hereinafter the OR), a biannual publication of the US government that reported, from 1816 to 1869 , the names and salaries of every federal government employee. We have concentrated on the salaries of postmasters because these salaries were based quite directly on the amount of business an individual post office did in a given year, according to a formula that changed from time to time. In other words, since one can tell from the OR exactly how much money a postmaster made in a given year, one can derive the amount of business that office did that year. We argue that the amount this figure, what we term "postal business" gives a very direct measure of economic activity at the local level for each two-year period, disaggregated to the level of individual post offices.

In this paper we present an analysis showing the strong relationship between postal business figures and local economic activity. It has long been accepted that when, in the $19^{\text {th }}$ century, a railroad came to a town, economic activity in that town greatly increased. This should be no surprise but the Official Register enables us to observe and measure this increase in economic activity, instead of merely presuming it. This indicates that Official Register data does provide, as noted above, a valid and reliable measure of local economic activity over both time, most of the $19^{\text {th }}$ century, and space, the entire United States. The outstanding source of reliable disaggregated economic data on the mid- $19^{\text {th }}$ century United States has been the census of 1850 , which recorded the value of each person's real estate, and the censuses of 1860 and 1870, which

1 http://www.archives.gov/publications/prologue/2004/winter/genealogy-official-register.html . See Terrence Hines and Thomas Velk (2010). The Official Register has been overlooked as a data source even in such major scholarly works as Nicholas Parrillo (2013). The first edition of the Official Register listed 6,327 federal employees and contractors in 176 pages. By 1905, the last edition in tabular format, it had grown to 4,219 pages and 349,075 names. The 1911 Official Register, the last to include the Postal Service, included 59,237 post offices. 
DIMAND, HINES, GONG, O'REILLY, VELK, ZHAO $19^{\text {th }}$ Century Economic Activity

recorded the value of each person's real and personal estate, providing the basis for Lee Soltow's landmark study, Men and Wealth in the United States 1850-1870 (Soltow 1975). The Official Register offers economic historians (and other historians) a comparable treasure-trove of data.

In our study, we go beyond economic consequences of railroad construction and discuss the influence of railroad activity on politics and social mobility. In our latest work, we use a recently published work of railroad history investments in the 19th century. The railroad history we have is highly detailed, naming particular towns and routes. Our own micro data will allow us to associate our postmaster data with railway town information at the same micro level.

Why are we using post-master data? Because postmaster salaries, which we have (or will have at the conclusion of our long-run project) for every post office in the USA, for every 2 years, after 1816 until 1869 were paid based on a formula linked to mail volume. We believe mail volume is a reasonable proxy for economic activity at the local level.2

Our data will also allow us to report the economic activity of non-railway towns. We will then have, at the micro-level, bi-annual comparisons made over the life of the railway routes. The relative economic, political and demographic impact of railway investment will be examined. For example, as we have the names, birthplaces and ethnic origins of postmasters in addition to their salaries, we can measure not just differences in economic activity between railway and non-railway towns but even examine questions like: "Are the railway towns places where new immigrants get to be postmasters more quickly than elsewhere?" We have discovered that women sometimes became postmasters. We asked if these women acquired their position because of their own social and political importance or whether the men in their lives (soldiers, father or male elites) were responsible. Our larger purpose is to advertise our ever-expanding postal based dataset, which provides information of interest to economists, sociologists, historians and political scientists.

Our main results show that being a railroad town creates significant differences in economic activity. That is no surprise, but our contribution is that we examine these differences at the micro level with highly frequent data. Our data shows that railroad towns have a much higher level of economic activity than do non-railroad towns; that economic activity in railroad towns are quite volatile; that evidence of national business cycles is much easier to see in railroad towns than in non-railroad towns; and that the demography of railroad towns, as measured by the names of postmasters is significantly different than it is in non-railroad towns.

\footnotetext{
${ }^{2}$ The postmaster compensation formula changed over time. In earlier presentations, we went into detail after the changes in the formula. We do not do so now, for reasons of space. Also, the impact of railway investment on town economic histories is so large and obvious we did not see a pressing need for finetuning. See COMPENSATION RATES in the appendix as a complete record of the formula and its changes.
} 
We note that one of the weaknesses of this investigation is that the number of railroad towns that we were able to examine is small. Thus, the averages for these railroad towns may sometimes display more volatility than is really there.

\section{Synopsis}

Our data is based on 6 states: Rhode Island, Connecticut, Massachusetts, Vermont, New Hampshire, and Maine. (Although our purpose here is to focus on the importance of railroads, it is interesting to note the emergence of Connecticut as a place with high mail volume, perhaps because of its connections with New York. Massachusetts, traditionally the lead player in New England, shows its importance throughout our essay). We compare non-railroad towns in a particular state with the railroad towns in that state. There was a complication here in that our sources of railroad history, Robert M. Lindsell and Ronald Dale Kerr (2000) and Ronald Dale Kerr (2014), discuss railway routes (connected towns that form a single entity). Sometimes those routes extend across state lines. In this initial venture into railway investigations, we ignore this route factor. We selected from 2-4 towns per route but we always confined the chosen towns to their respective states when we made our comparison with non-railway towns in those states. Some towns are large (e.g. Boston and Providence) but shared a route with a town that might be quite small. Compensation averages would change as, over time, small towns are added to large towns. To avoid this misleading volatility in average compensation per town, our data was expressed in terms of rate of change.

Our postal data begins in 1816. Rail routes were initiated at different points in time after that. Graph 1 shows the first railroad routes we examined started in 1835 .

All our railway routes remained in service until 1869 and in most cases, well beyond that date. But our postmaster data ends in 1869. Our railway routes all began as independent financial entities. But overtime, many of them became consolidated into larger rail networks. Our data does not explicitly account for possible effects of this consolidation. In any case, we have not separated the route factor out for analysis.

Graph 1 shows the average compensation of postmasters in the New England states. Notice the pro-cyclical nature of the data. We have shown, to our satisfaction, that postmaster compensation fluctuations match business cycles estimated and discussed by other scholars and institutions (see for example, NBER). ${ }^{3}$ In Graph 2, the railroad towns in the six New England states exhibit matching pro-cyclical behavior with the greatest volatility seen in the more "developed" states like Connecticut and Massachusetts, less so in agricultural Vermont.

\footnotetext{
${ }^{3}$ National Bureau of Economic Research (NBER) http://www.nber.org/cycles/cyclesmain.html
} 
DIMAND, HINES, GONG, O'REILLY, VELK, ZHAO $19^{\text {th }}$ Century Economic Activity Graph 1

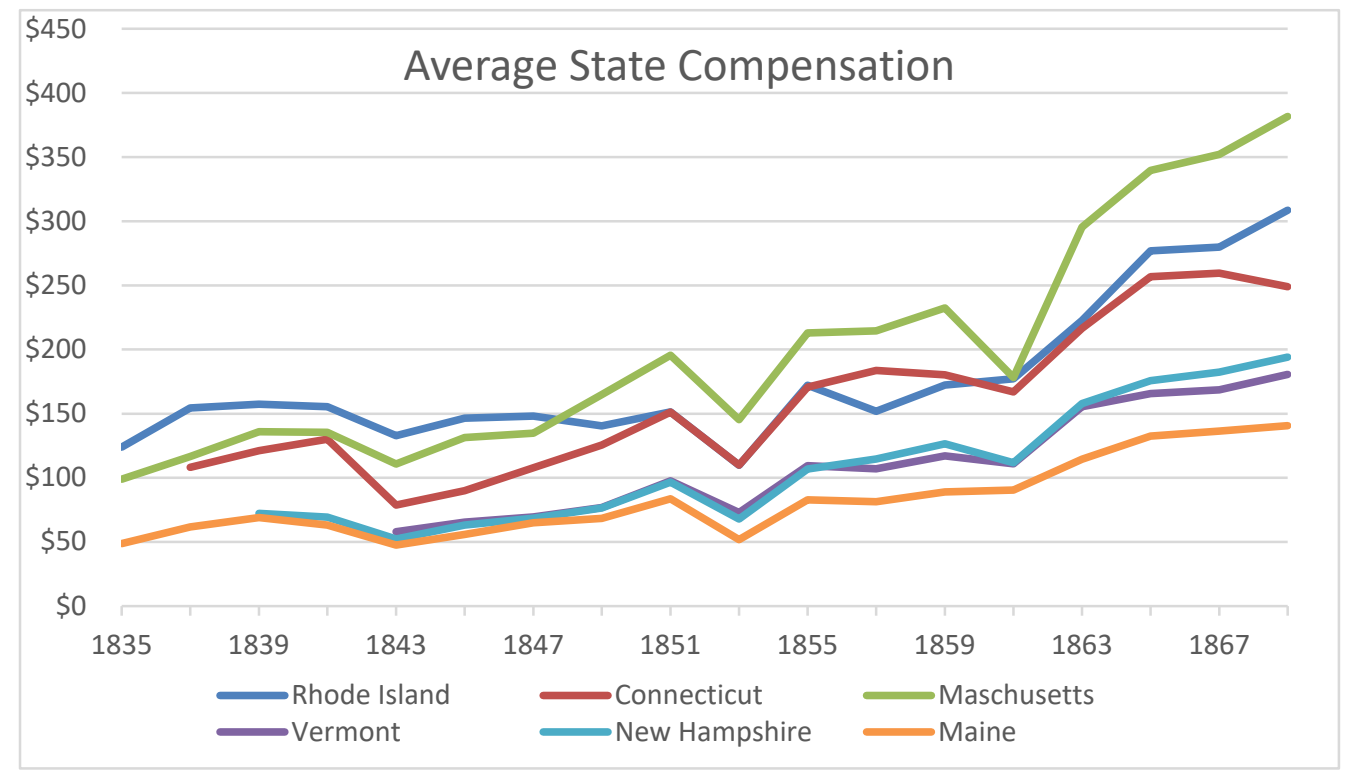

Graph 2

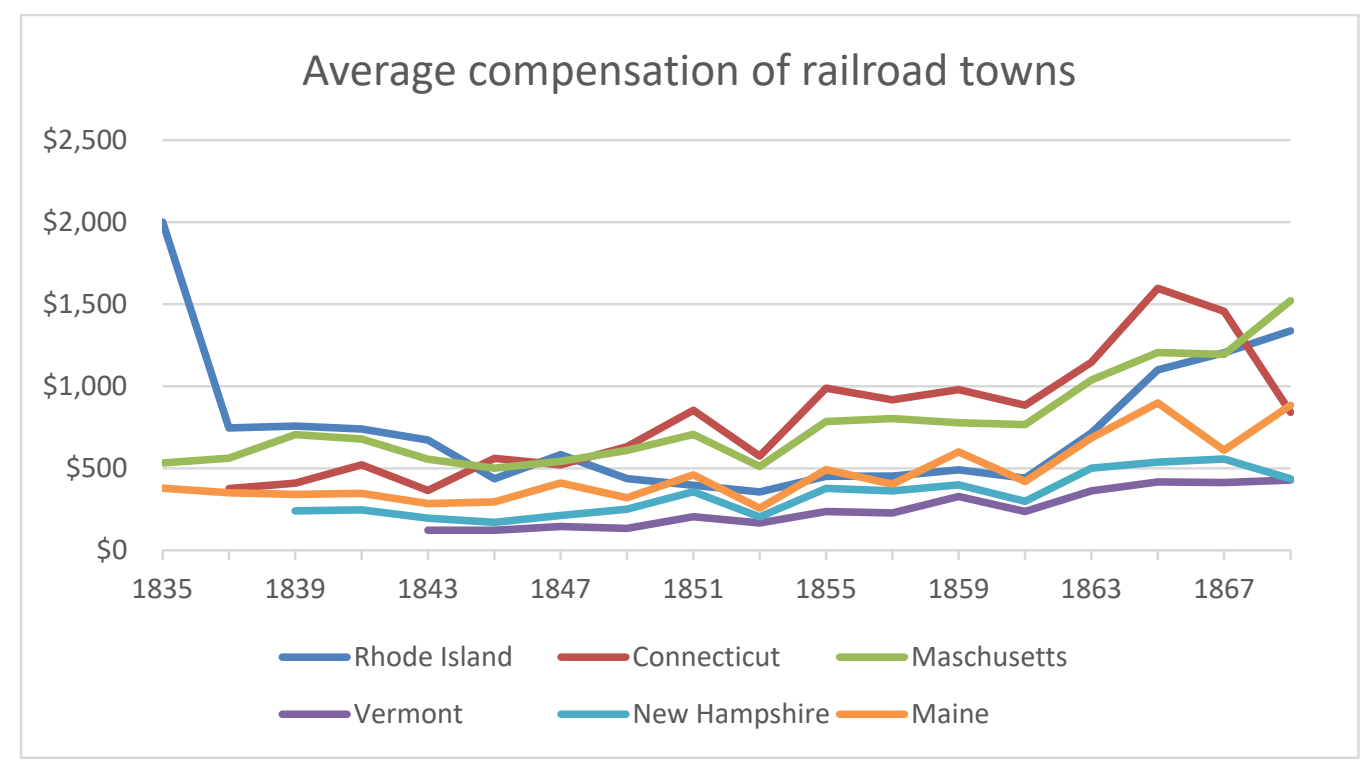

You may be expecting a chart that compares towns where the railroad is the only differentiating factor with towns that have no railway service whatsoever. Our charts are not so 
ideal. Consider a timeline for postmaster pay rates of change for the average (say) Vermont town beginning in 1816. No town anywhere yet has a railroad. The timeline will show business cycle volatility, but there will be no separate line for railway towns, only standard (non-railway) towns. Beginning in 1835, some towns become railway towns, and our chart now has two timelines: one for postmaster rates of change in railway, and one for non-railway towns. The railway towns were probably always special. These "chosen" towns were likely selected by railway investors because they were always active, promising business locales. So the towns that migrated out of the non-railway line and "flew up" to the railway towns probably would have been more sensitive to the business cycle and more interconnected to the rest of the world. Our analysis does not fully account for that. Moreover, some towns that we designate as nonrailway towns were actually part of the extensive route system that quickly grew up after 1835 . We have not been able to completely sort out these cases. The result is that towns mistakenly placed by us in the set of non-railway towns will in fact show the volatility and dynamism that is the consequence of their true state. Moreover, since our set of designated railway towns does not include all towns that were in fact possessed of railway services our estimation of the true record of their economic activity is imperfect.

In a future revision of this paper we will trace the "before" and "after" picture of towns that were chosen for railway investment: we will ask how different they are from towns that never acquire railway status. But this research strategy will not eliminate the complication that chosen towns always had pre-existing economic attractions that differentiated them from average towns. Thus any conjectural history for chosen towns that assumed they did not acquire railway investments would quite possible always find such places to be especially dynamic and prosperous.

There is a complicated interaction among postal expenditures, postal services, railroads and railway towns for which we do not yet account. All railways in the U.S, from the beginning of rail service, ${ }^{4}$ received special subsidies from the Postal System. Eventually trains hauled special railway cars containing expert postal clerks and postal sorting paraphernalia. These personnel and their equipment greatly improved the efficiency of mail sorting and delivery along railway routes. The specialized clerks themselves were paid salaries (not linked to mail volume) in excess of $\$ 2000$ per year, a large sum in those times. These clerks and their salaries did not diminish the payment made to the postmasters along the railway route. The mail that was sorted and transferred in the special postal cars were first handled, on the outgoing side, and later accounted for on the incoming side of the local postmaster salaries formula. Our use of the postmaster compensation was not made less accurate because of the postal cars and clerk factor. However, the impact of the railroad on the railroad town was greater because the railroad's presence was augmented by the subsidy it received from the Postal Service.

\footnotetext{
${ }^{4}$ http://postalmuseum.si.edu/rms/history/mailbyrail.html
} 
DIMAND, HINES, GONG, O’REILLY, VELK, ZHAO $19^{\text {th }}$ Century Economic Activity

We also examined the demographics of all our postmasters in four states: New Hampshire, Vermont, Connecticut, and Massachusetts. In a later study, we will separate the data between railroad town postmasters and non-railroad town postmasters. For now, we are able to say although a postmaster job was a sign that the receiver had enough political influence to earn an appointment nominally from the President of the United States, the ethnic origins of our postmasters were not concentrated in the elite population. That is, one might expect, that given the political connections needed to get one of these jobs, old line Protestants with what we have called Mayflower names were certainly present but so were Irish, Jewish, and other European origins. $^{5}$

\section{Railroad Analysis: Rhode Island ${ }^{\mathbf{6}}$}

\section{Observations:}

In Rhode Island the average compensation of postmasters in railroad towns is consistently higher than the state average. There is a drop off in the railroad town compensation average, between 1835 and 1837, from $\$ 2000$ to $\$ 746.04$ respectively, because of a change in the sample: Providence, the state capital, was the state's only railroad town in 1835 but was one of three in 1837. The average compensation remains in the mid- $\$ 700$ range until 1844 . This value then drops in 1845 to $\$ 438.28$. Despite the slight increase in 1847 , the railroad compensation averages trend down between 1845 and 1853. Between 1855 and 1861 the railroad town compensation averages stay within the range of $\$ 441.06-\$ 491.12$. During this period, of 1855 1861 , the greatest rate of change is between $1859-1861$ with a $-10.19 \%$ rate of change. After 1861 there is a significant increase in the railroad town compensation averages from $\$ 441.06$ in 1861 to $\$ 715.60$ in 1863. A likely cause is an increase of Civil War-driven mail volume, rather than "real" economic activity. From 1863-1869 the compensation averages for railroad towns trends upwards reaching a value of $\$ 1337.92$ in 1869 , a value only surpassed in 1835 .

The line graph for Rhode Island's state average postmaster compensation (Graph 3) shows both contrasts and similarities when compared with the railway town numbers.

Unlike the railroad town averages between 1835 and 1837, state-wide there is a positive rate of change of $24.63 \%$. There is an increase of almost $71 \%$ for railway towns in postmaster compensation between 1841 and 1843. The state average is not very volatile between 1847 and 1851. During this 4 year period the state average compensation remains within a $\$ 140-\$ 150$

\footnotetext{
5 We were able to access the list of Mayflower surnames from http://www.genealogyforum.rootsweb.com/gfaol/surnames/Mayflower.htm

${ }^{6}$ The outlying value of postmaster compensation for railroad towns in Rhode Island in 1835 is because the state's only railroad town in that year was the state capital, where the state government generated a large volume of postal business.
} 
Graph 3

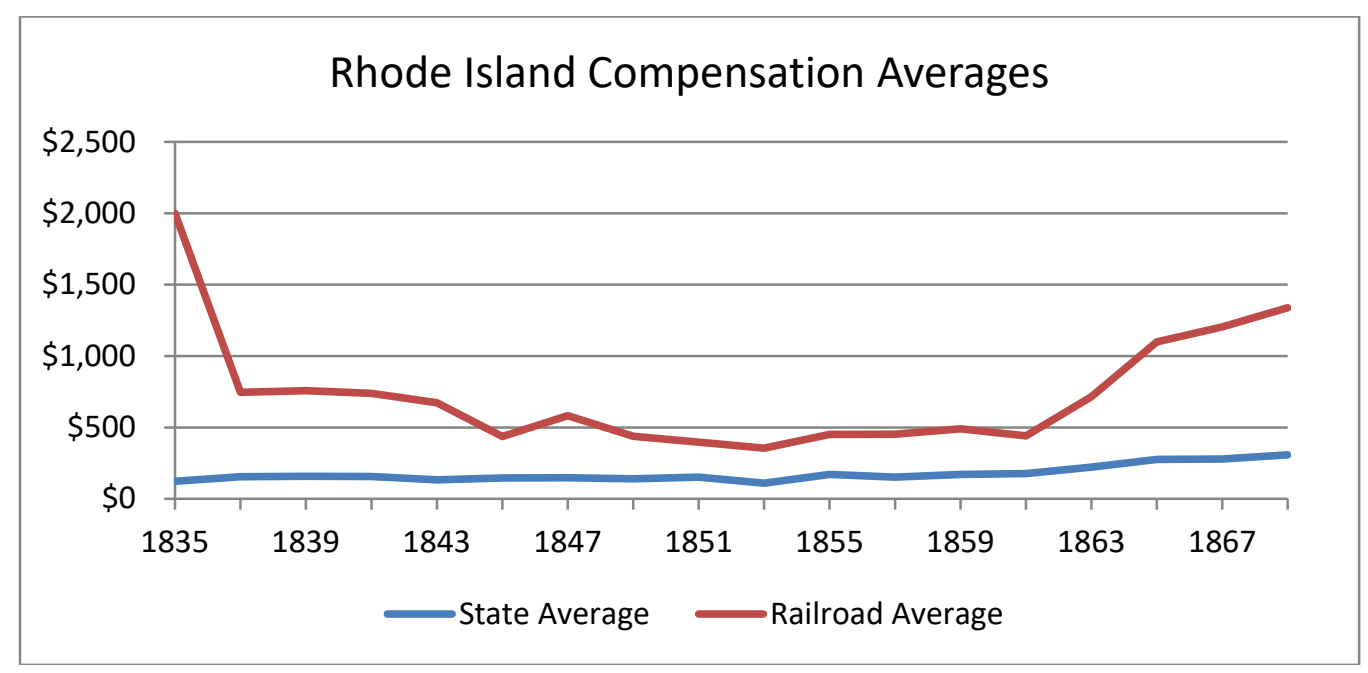

Graph 4

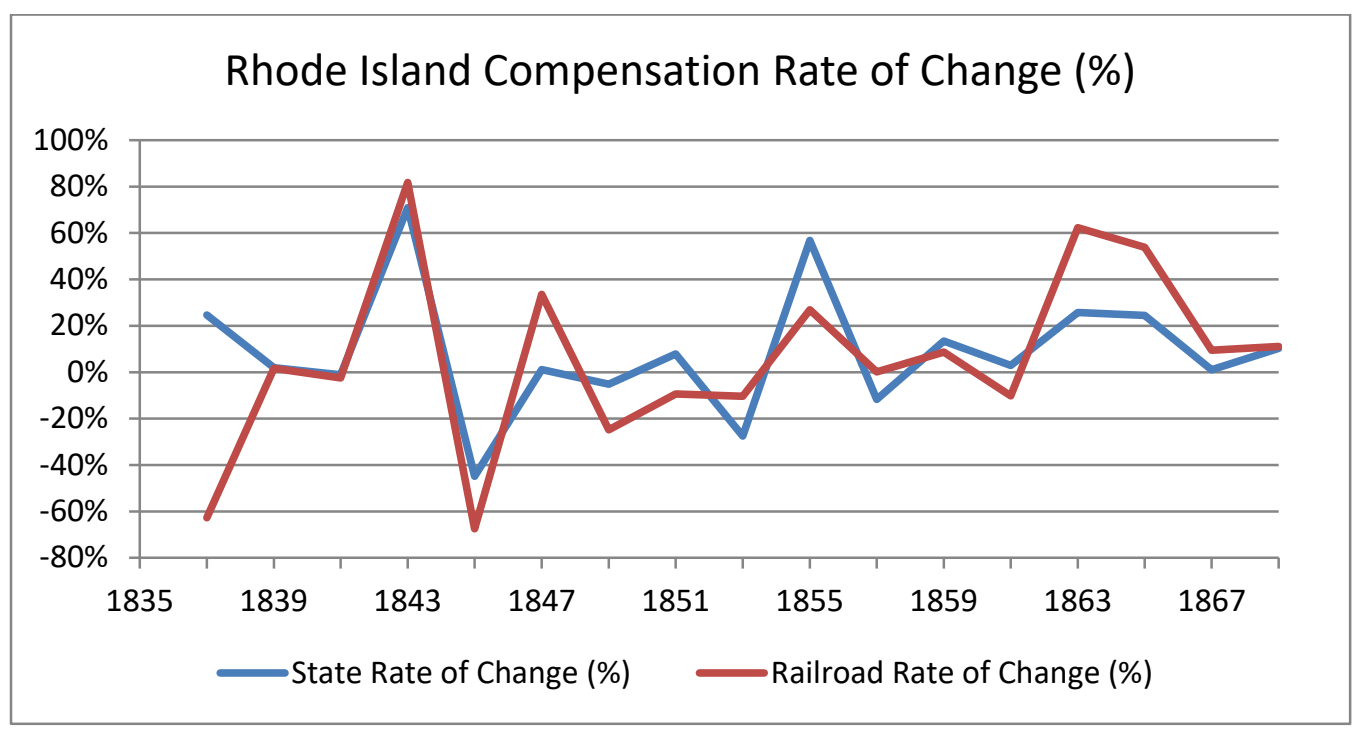

range. The rate of change (Graph 4) during this time is moderate; the steepest is $7.82 \%$ between 1849 and 1851.

In 1853, like the railroad average compensation graph, there is a drop in the average compensation. In 1853 the compensation drops to $\$ 109.73$ from $\$ 151.43$, a rate of change of $27.54 \%$. The average compensation increases dramatically in 1855 to $\$ 172.02$. There is a drop to $\$ 151.84$ in 1857 . Thereafter, the averages between 1855 and 1861 are relatively close to one 
DIMAND, HINES, GONG, O'REILLY, VELK, ZHAO $19^{\text {th }}$ Century Economic Activity

another. The likely impact of the Civil War is evident. From 1863-1869 the compensation averages for railroad towns trends upwards reaching a value of $\$ 308.52$ in 1869 , the highest value in the span of 1835-1869.

There is quite a bit of volatility in railroad towns' per capita values (see Graph 3). In the early data, there is a dramatic drop from $\$ 0.042537$ in 1833 to $\$ 0.011950$ in 1835 , this being a rate of change of $-71.91 \%$. Between 1835 and 1839 the postmaster compensation per capita seen in railroad towns remained relatively stable. The rate of change is $1.66 \%$ and $-2.46 \%$ respectively. Between 1839 and 1845 there is quite a bit of volatility. Between 1839 and 1841 there is a dramatic increase in the railroad towns per capita postmaster compensation with a rate of change of $81.75 \%$. This was followed by a dramatic drop in the growth rate of compensation between 1841 and 1843. Between 1845 and 1859 the railroad towns per capita compensation value trends down. However, between 1859 and 1867 it begins to move up, finishing with a per capita value of $\$ 0.009653$.

State average per capita compensation numbers are significantly lower than those for the railroad towns. The state per capita values are quite volatile. Between 1839 and 1845 there are dramatic shifts. Between 1837 and 1839 there is an $-11.74 \%$ rate of change followed by a $70.85 \%$ rate of change between 1839 and 1841 . Between 1849 and 1855 the average postmaster compensation per capita of the state is downward sloping with 4 consecutive negative rates of change values. There is a period of stability between 1857 and 1861 where the rate of change is small. However, in 1861 there is a dramatic drop with a $-26.10 \%$ rate of change. Despite the aforementioned drop, between 1863 and 1869, the state level per capita compensation trend up, finishing in 1869 with a value of $\$ 0.001767$.

\section{Analysis:}

Rhode Island's postmaster compensation data shows the effect of both a national business cycle and as well, events unique to the state. In 1835 the compensation average is $\$ 2000$ for railroad towns. In 1837 it is $\$ 764.04$. In 1835 Providence, the capital of Rhode Island, and so likely to have a high compensation number, was the only railroad town. In 1837 two smaller towns became railroad towns. Their postmasters earned low salaries, because postal volume was much lower in those small towns than in the state capital. When we divided the total railroad compensation of $\$ 2,238.12$ by 3 the average dropped dramatically. This same drop is evident in the per capita values for railroad towns between 1835 and 1837, where there was a $71.91 \%$ shift. These data were not a testament to any historical or economic factors but rather a byproduct of our data collection methodology. And so we report the per capita rate of change and rate of change for state postmaster compensation, and discover that the compensation data is consistent with business cycle dates established by others. The national economy between 
1834 and 1837 was in a period of expansion, growing in real terms. ${ }^{7}$ The Rhode Island numbers (24.63\% rate of change for state postmaster compensations and state compensation per capita increase of $24.63 \%$ ) show that the Ocean State was moved by the general tide of economic events.

In the mid-1840s, there was a national recession. Economic affairs were further complicated by the Dorr Rebellion of 1842-1843. In November of 1842 Thomas Dorr fought for changes in the voting laws of Rhode Island. ${ }^{8}$ At that time only men who owned at least $\$ 134$ in land could vote. ${ }^{9}$ Thomas Dorr fought to enlarge suffrage. Dorr was convicted of treason and incarcerated. His efforts compelled the Rhode Island government to pass a new constitution that extended suffrage and afforded citizens expanded economic rights. ${ }^{10}$ For example, Article 1, Section 12 of the 1843 constitution reads, "there shall be no law that impairs the obligation of contracts." 11 This might explain why the salary of the postmaster in Providence increased between 1841 and 1843 from $\$ 1980.77$ to $\$ 3659$.3. The mails were more active and postmaster compensation was greater possibly because of increased immigration.

In 1853 there is a drop in the state average compensation from $\$ 151.43$ in 1851 to $\$ 109.73$ in 1853. Similarly there was a per capita rate of change of $-27.54 \%$. These numbers perhaps reflect the 1853 United States recession. ${ }^{12}$ The 1853 recession was characterized by low growth in the United States economy. American business contracted by $18.4 \%$, as interest rates rose and railroad investments decreased substantially. ${ }^{13}$ It's likely that as a result of this change in economic growth, the postmaster's salaries in the state of Rhode Island dropped. There was a similar drop in the railroad towns compensation averages by $-10.45 \%$.

In 1857 the state compensation average has a negative rate of change of $11.73 \%$ and an identical negative per capita rate of change. There was a national recession in 1857. In 1857 the value of land fell and migration slowed causing railroad securities to fall in value. ${ }^{14}$ A number of railroad lines shut down. ${ }^{15}$ There were significant job losses. ${ }^{16}$

There is an upward trend in 1861-1865 for the compensation averages for both railroad and non-railroad towns. In 1861 the railroad town compensation is $\$ 441.06$, increasing to $\$ 715.60$

\footnotetext{
${ }^{7}$ Davis (2006): 106.

${ }^{8}$ Brooke (1993): 193.

${ }^{9}$ Brooke (1993): 196.

${ }^{10}$ Brooke (1993): 196.

11 "The State of Rhode Island Constitution." http://webserver.rilin.state.ri.us/RiConstitution/.

${ }^{12}$ Davis (2006): 109

${ }^{13}$ Davis (2006): 106.

${ }^{14}$ Huston (1983): 21.

${ }^{15}$ Huston (1983): 17.

${ }^{16}$ Huston (1983): 17.
} 
DIMAND, HINES, GONG, O'REILLY, VELK, ZHAO $19^{\text {th }}$ Century Economic Activity

in 1863 and $\$ 1,100.31$ in 1865 . In 1861 the state compensation is $\$ 177.05$, increasing to \$222.57 in 1863 and \$276.91 in 1865 . Between 1861 and 1865 economic activity was disturbed by war and economic dislocation. ${ }^{17}$ After the Civil War, Rhode Island's railroad infrastructure was expanded to connect the North and South. ${ }^{18}$ Rhode Island became better connected with the rest of the nation. ${ }^{19}$ In 1865 , postmaster compensation grew by $53.76 \%$ in Rhode Island, more than double the rate experienced in non-railroad towns.

In all Rhode Island towns, railway and non-railway, there was extensive volatility in postmaster compensation between 1835 and 1865. A possible weakness in our analysis is that we have only thirteen railway towns. ${ }^{20}$

\section{Railroad Analysis: New Hampshire}

\section{Observations:}

New Hampshire's first railroads were built in 1839. The state average postmaster compensation climbs steadily upwards. There is a trend, evident everywhere in the county, of increasing use of the mails. This is driven by the falling real cost of postage, rising real incomes, and a more complex and interconnected economy that required intercommunication to serve the needs of a more specialized and interconnected national production function. Railroad town postmaster compensation data sharply rises and falls around the trend line. This can be attributed to the significantly smaller sample size of the railroad town data in comparison to the statewide data. Nonetheless, the all-state (rail town and non-rail town) and railroad town data sets mimic each other.

Comparing New Hampshire all-state average postmaster compensation values to the average compensation rates paid in the towns with railroads shows a similar pattern, with railroad town data quite a bit more volatile. Also, the rail towns have markedly greater levels of economic activity: that is, their postmasters earn more than do the rest of their cohort, employed in non-railroad towns (Graph 5).

Both the railroad average and the state average followed the same general pattern, with compensation rates increasing over time. The state average begins at $\$ 72.27$, and increases (with many peaks and troughs in between) to a high value of $\$ 193.98$ in 1869 . The lowest point in this trend is $\$ 62.99$ in 1845 . There are moderate peaks in $1843,1851,1859$, and following 1861 a general upward climb until the end of the reported data in 1869. The railroad average

\footnotetext{
${ }^{17}$ Davis (2006): 106.

${ }^{18}$ Simon (1963): 524.

${ }^{19}$ Simon (1963): 524.

${ }^{20}$ See Figures 1, 2 and 3 in the Appendix for further graphs to enhance comprehension of data.
} 
Graph 5

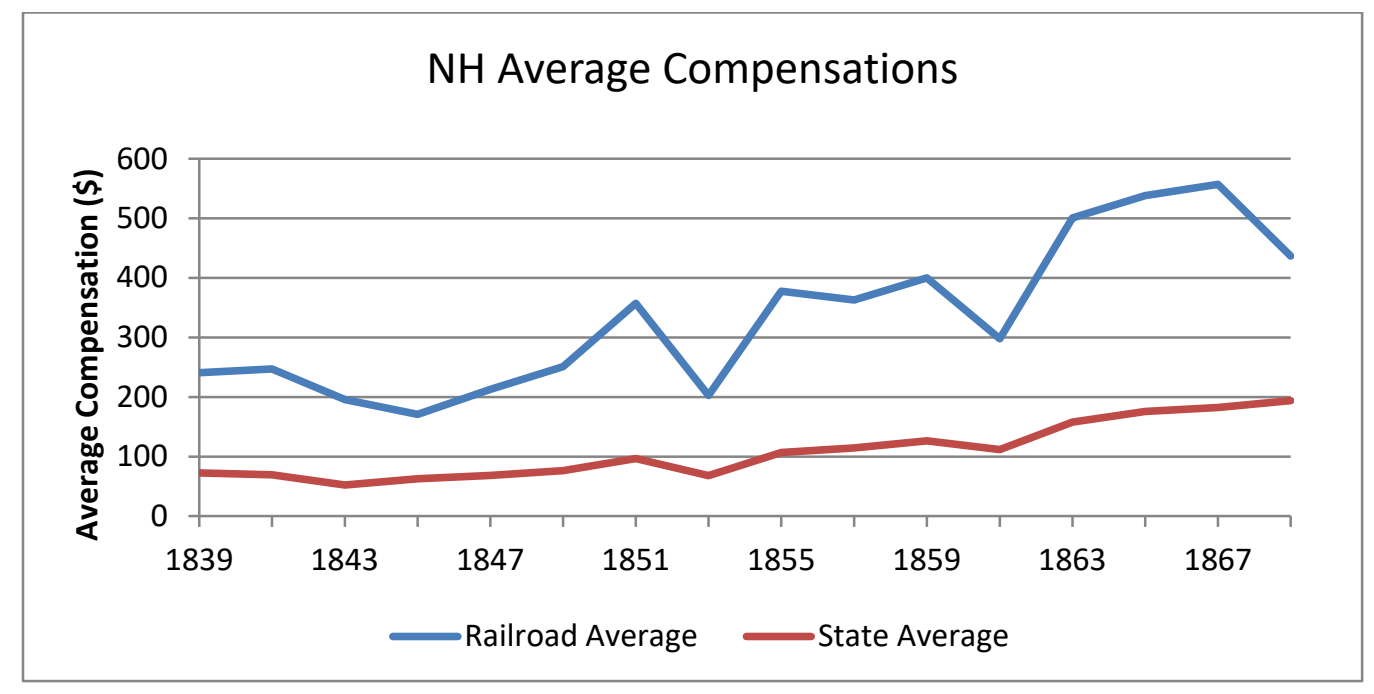

begins at $\$ 241.01$ in 1839 , a difference from the state's average compensation starting point of over $\$ 150.00$. The railroad average data ends in 1869 at a value of $\$ 436.86$. The lowest point throughout the timespan is $\$ 170.77$ in 1845 , while the high point is in 1867 with a value of $\$ 557.16$. A previously stated, the railroad average compensation data has a much more volatile path, with extreme peaks in $1843,1851,1855,1859$, and 1867 , as well as corresponding troughs. The most extreme rise between two data points in the railroad averages is between 1861 and 1863 , where compensation rises from $\$ 298.16$ to $\$ 500.88$. The most extreme drop between two data points in the railroad average dataset is between 1843 and 1845, where the compensation rates fall from $\$ 391.04$ to $\$ 170.77$.

Using as our metric the rate of change in postmaster compensation levels in New Hampshire between 1839 and 1869 gives results to those found when the measure is compensation averages (Graph 6).

The railroad rate of change presents the same trends as the state rate of change, but it is moderately more volatile. The railroad and state rates of change mimic one another except in a few notable exceptions. Between 1847 and 1849, the state rate of change is a positive one, while the railroad rate of change decreases. Finally, between 1867 and 1869, the state rate of change is positive, while the railroad rate of change is negative.

\section{Analysis:}

Just looking at the two histograms (Graphs 5 and 6), one may conclude that state averages for compensation are higher in towns with railroads than in towns without. The state compensation data has multiple significant peaks, including, but not limited to, in 1843, 1851, and 1865. 
DIMAND, HINES, GONG, O'REILLY, VELK, ZHAO $19^{\text {th }}$ Century Economic Activity

Graph 6

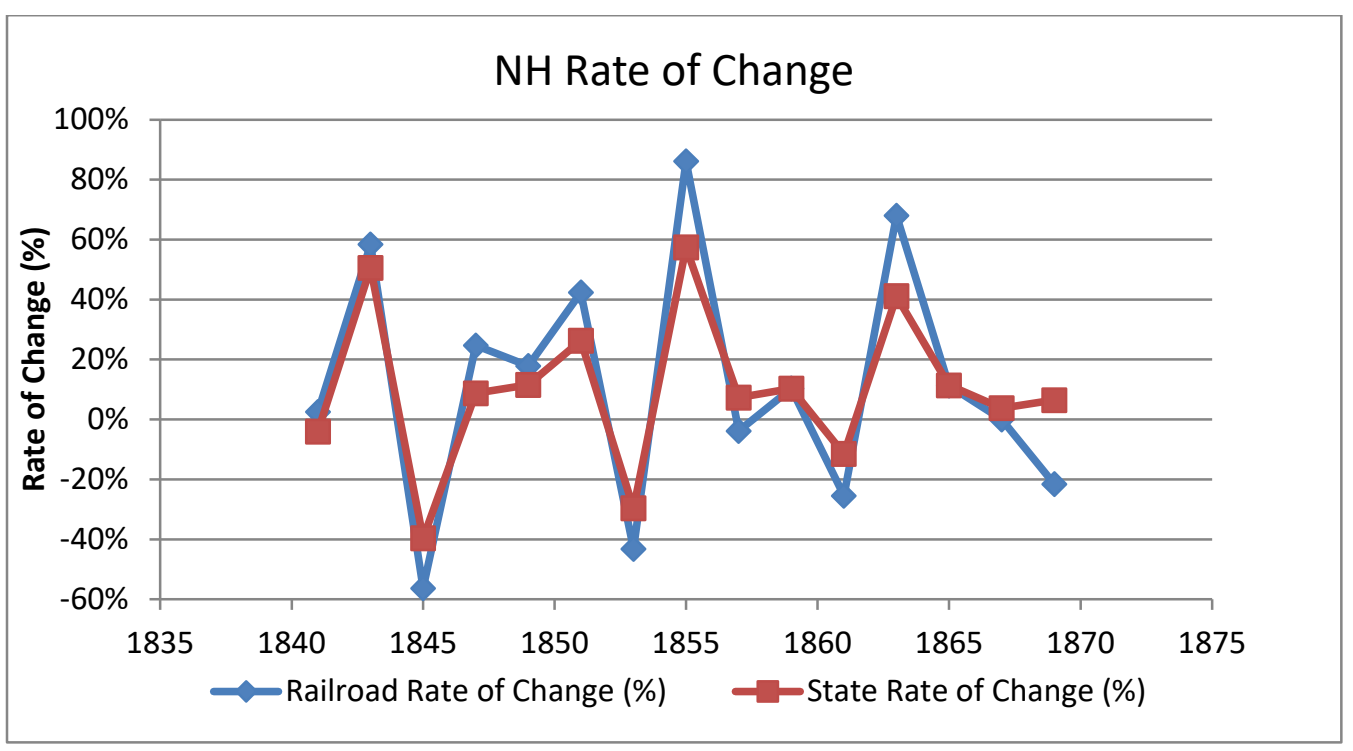

It is evident that there is more economic activity in towns with railroads. It seems equally likely that there is more volatility in those towns. Our data shows this with a fair bit of detail. One can see the impact of Civil War (1861-1865). It seemed to most strongly affect railroad towns. In both all-state towns (a combination of railroad and non- railroad towns) and railroad towns, there is a rise in compensation levels from 1861-1865. The same is true for the rate of change histograms, for the period from 1861-1863. From 1863-1865 there is a clear drop in the rate of change values. It is interesting to note that New Hampshire, though fourth in population, ranked second in rail coverage in New England. ${ }^{21}$ This is a potential contributing factor to the increasing compensation levels; as the state had such a good rail network, it saw increased movement of goods and mail throughout the war, therefore increasing compensation levels for postmasters (seen as a reflection of increased economic activity).

Contradicting this, however, is the fact that New Hampshire saw a great outwards migration in the early years of the war. A total equal to $13.5 \%$ of New Hampshire's 1860 population had moved to Massachusetts by that same year. ${ }^{22}$ This can be attributed to increased opportunities in the industrial sector in Massachusetts, and very average agricultural opportunities in New Hampshire, relative to neighbouring states. ${ }^{23}$ Richard Miller, in his book States at War (2013), points to a gender disparity in New Hampshire at the beginning of the Civil War, resulting in

${ }^{21}$ Miller (2013), p. 360.

${ }^{22}$ Miller (2013).

${ }^{23}$ Miller (2013). 
additional conscription challenges for the New England state. The gender disparity (more women than men) could also account for why mail volume potentially increased in New Hampshire throughout the war, as female family members relied on the postal system to keep in contact with male family members who had moved to a nearby state for employment opportunities. Beyond New Hampshire's specific context encouraging increased postal use, the Civil War inevitably led to increases in mail and the postal system as many previously local activities were suddenly spread out over great distances.

Prior to the outbreak of the Civil War, the United States had a series of economic downturns in the mid- $19^{\text {th }}$ century. The recession of the 1840 s, the aptly named the Panics of 1837 and 1857, and the Secession Winter of 1860-1861, all impacted the youthful republic's economy. Interestingly, most of these did not seem to affect the compensation rates in New Hampshire. The one exception to this, perhaps, is the decrease in compensation values throughout the 1840 s, which could potentially be attributed to the economic recession of the 1840s.

The National Bureau of Economic Research offers an organized assessment of business cycles between the $1700 \mathrm{~s}$ and the beginning of the $20^{\text {th }}$ century, and Davis provides a revised method of analyzing business cycles, using Davis's annual industrial production index. ${ }^{24}$ The NBER business cycles have very little direct correlation with the New Hampshire railroad town average compensation graphs. Between each peak and trough as identified by the NBER, an expected drop in compensation rates could be anticipated, yet this is not the case for the railroad towns. One possible explanation for this is that the rail towns' economic activity was independent of broader business cycle impacts. In other words, perhaps the powerful growth factor associated with innovative transportation was so powerful locally, that it overwhelmed the general decline in economic activity. This theory, however, would assume that the state average compensation rates would follow the business cycle peaks and troughs more closely, yet, as discussed in the observations, the state and the rail town data averages are very closely correlated. Therefore, the business cycles as identified by the NBER and Davis do not match the compensation data for New Hampshire from 1839 to 1869. Another explanation is that an agricultural state like New Hampshire was, to an extent, exempt from a business cycle that more powerfully impacted the industrial and financial communities of New York, Boston and Philadelphia.

Another explanation for why the NBER data does not exactly match the New Hampshire compensation data is that though it does not directly correlate, there is a lagged match. New Hampshire's peaks and troughs occur two years following the NBER's identified business cycles. The NBER data is observed at macro-level. Our postal data is micro, immediate and accurate. It is not impossible that our dates are better than the NBER's. ${ }^{25}$

\footnotetext{
${ }^{24}$ Davis (2006): 103-121.

${ }^{25}$ National Bureau of Economic Research (NBER), "US Business Cycle Expansions and Contractions," accessed 31 March 2015 from http://www.nber.org/cycles/cyclesmain.html
} 
DIMAND, HINES, GONG, O'REILLY, VELK, ZHAO $19^{\text {th }}$ Century Economic Activity

\section{Railroad Analysis: Massachusetts}

\section{Observations:}

Here reported is our measure of economic activity in Massachusetts' railway towns and all towns (non-railway plus railway towns) (Graph 7).

Comparing the postmaster compensation data from the all-state average to the railroad towns in 1835-1867, it is apparent that economic activity is more volatile in the railroad town data, (although some of this results from working with a smaller number of railroad towns than we would like) it seems clear that the railroad towns had, on average, a higher level of economic activity than did the typical state town. The state average compensation data shows a slow but fairly steady increase, beginning at $\$ 116.56$ in 1835 and peaking in 1867 at $\$ 381.65$. Other than the overall increase in postmaster compensation, the graph reveals a steep peak at 1841, in which the compensation average rises from $\$ 135.35$ in 1839 to $\$ 221.56$ by 1841 , and returns back to $\$ 131.26$ by 1843 . Other dramatic changes in economic activity occur in 1851 , in which the activity drops from $\$ 195.41$ in 1849 to $\$ 145.29$ by 1851 , and back up to $\$ 212.91$ by 1853 . The last dramatic change in economic activity occurs in 1859 in which the activity drops from $\$ 232.44$ in 1857 to $\$ 178.12$ by 1859 , then returns to $\$ 295.38$ by 1861 , from which it steadily increases until 1867. This slow but steady increasing compensation data for the state average stands in stark contrast to the railroad town averages, which reflect a volatile but extreme increase over the course of the graph. Beginning in 1835, the railroad town data begins far above the highest point for the state averages, at $\$ 561.12$. The railroad town average

\section{Graph 7}

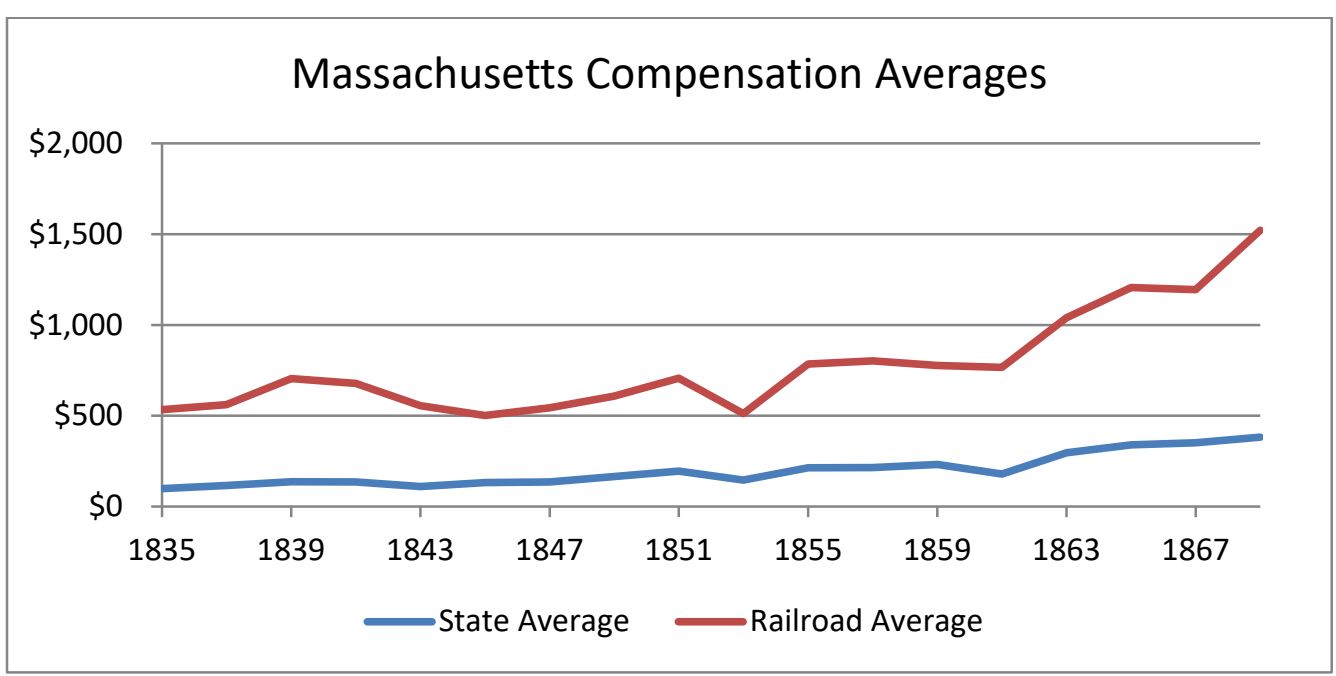


compensation shows a strong upward trend. The most dramatic peak occurs in 1841, in which the compensation data rises from $\$ 678.70$ in 1839 to $\$ 1,111.13$ by 1841 , only to return back, even lower than before, to $\$ 500.94$ by 1843 . Other significant changes in economic activity occur from 1849-1851, in which the compensation drops from $\$ 705.97$ to $\$ 511.30$, and returns back to $\$ 784.79$ by 1853 .

In comparing the rate of change data in economic activity in the state as a whole to the railroad towns (Graph 8), we see that the state's pattern of rate of change is echoed, but with amplification, by the railroad towns: the rates of change in the state and the railroad towns move in the same directions (in terms of positive and negative change) at the same time. However, that the rate of change in railroad towns is more extreme in both directions.

\section{Analysis:}

The Massachusetts postmaster compensation data, at both the state level and in the railroad towns, largely reflects the macro trends that characterized the economic centres of the US at this time. For example, the dip in the average compensation data in 1849-1851 is consistent with the recession experienced across America during this period. ${ }^{26}$ There is lower compensation in the all-state numbers, seen by a subtle dip in the graph at this time. The slowdown is echoed in the data for railroad towns: there is a trough during this period (Graph 5).

\section{Graph 8}

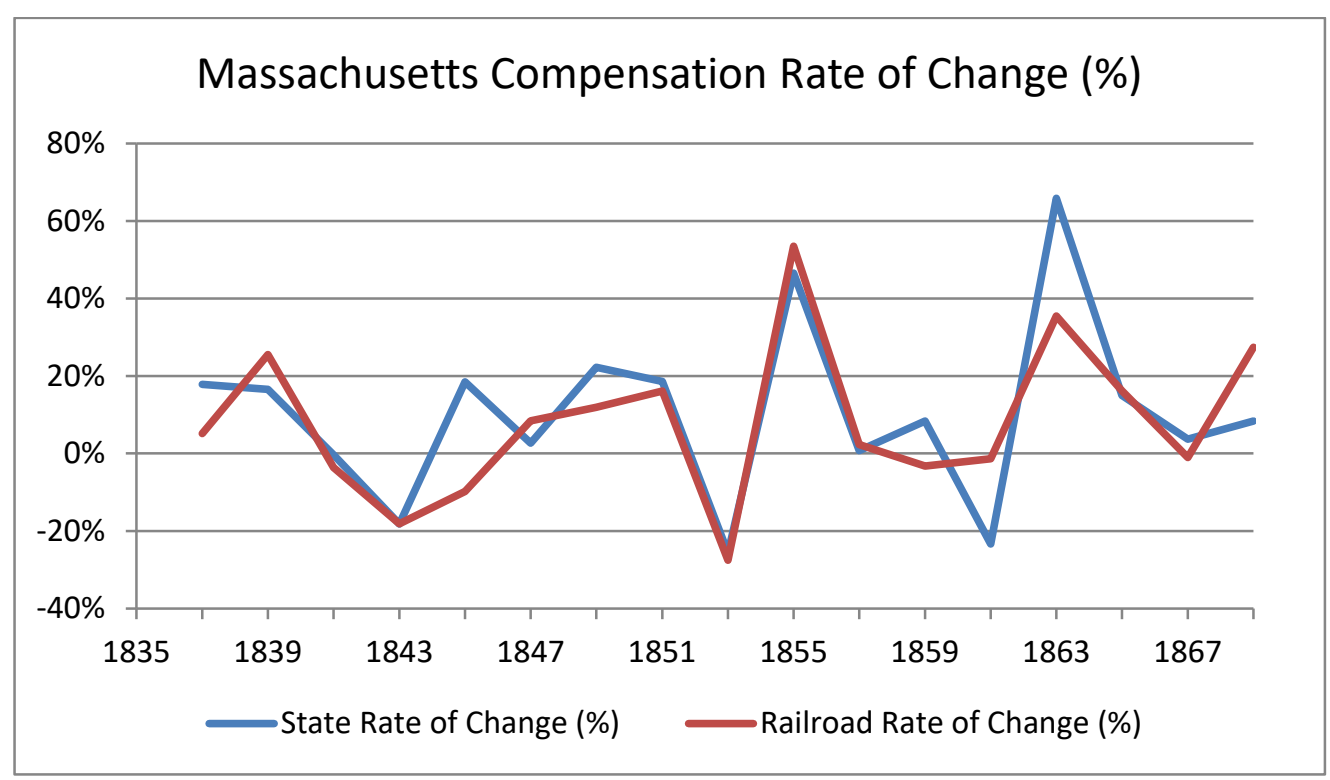

${ }^{26}$ Peter Temin (1969). 
DIMAND, HINES, GONG, O'REILLY, VELK, ZHAO $19^{\text {th }}$ Century Economic Activity

The advantage of our data set is its micro level, local quality. So our analysis is able to show, at the local level, exceptions to the greater trends. For example, the compensation data does not reveal a dip during the recession of 1837, which suggests that New England (including Massachusetts) was less damaged by that recession as was the rest of America. ${ }^{27} 28$

Another macro trend experienced by Massachusetts is increased use of the mail during the war years, 1861-1867. In that interval the volume of the mail increased at a quicker rate for more years in a row than at any other five-year span in this dataset (Graph 5). This trend is evident in both state average compensation and railroad town average compensation, though, expectedly it is shown more dramatically in the railroad town compensation. The increase in letter-writing in a northern state like Massachusetts is unsurprising since most of the postal monitoring at this time was done in the South. ${ }^{29}$ The economic activity in Massachusetts was also ranked $5^{\text {th }}$ nationally at this time, which is consistent with the peak in the data and relatively high compensation that characterizes Massachusetts, compared to other states (Graph 1). ${ }^{30}$

Another macro trend expressed at a local level in Massachusetts is that of immigration. America was accepting lots of immigrants in this period, with a major wave from Northern and Western Europe occurring from 1815-1865, with a large contingent from Ireland. ${ }^{31}$ Massachusetts felt this wave of immigration especially in the 1840s, as there was significant immigration to Massachusetts from European countries. The Massachusetts textile mills employed many immigrants and greatly contributed to the economic activity. ${ }^{32}$ One may hypothesize that many immigrants used mail to write to folks back home, adding to mail volume, and attesting to the economic boost their new employment was generating.

After consulting Joseph Davis's seminal article, “An Improved Annual Chronology of U.S. Business Cycles since the 1790s" (2006), the only business cycle outlined in this article that aligns with his dates for Massachusetts economic activity is the thriving of the economy from the years 1846-1847 (Graph 5). ${ }^{33}$ However, the business cycles defined by the National Bureau of Economic Research matches our description of varying economic activity in Massachusetts quite effectively. ${ }^{34}$ The NBER says the economic activity during the time window we study in this essay in Massachusetts paralleled the greater business cycles occurring in the US. Our

\footnotetext{
${ }^{27}$ Michael Bordo (2003).

${ }^{28}$ Rolnick, Smith, and Weber (2000): 3.

${ }^{29}$ Burke, Kathryn. "Letter Writing in America - Postal Museum." National Postal Museum. Accessed March 22, 2015. http://postalmuseum.si.edu/letterwriting/index.html.

${ }^{30}$ Miller (2013).

31 "U.S. Immigration Before 1965." History.com. 1 January 2015. Accessed 23 March 2015. http://www.history.com/topics/u-s-immigration-before-1965.

${ }^{32}$ Miller (2013).

${ }^{33}$ Davis (2006).

${ }^{34}$ National Bureau of Economic Research (NBER). "US Business Cycle Expansions and Contractions." Accessed March 31, 2015. http://www.nber.org/cycles/cyclesmain.html.
} 
story agrees with that of the NBER. The increase in economic activity from 1854-1857 and 1861-1867 is reflected in the postmaster compensation data, as well as is the decrease in economic activity in 1857-1858. Thus, overall, Massachusetts's economic activity, as indicated by postmasters' compensation, is a good representation of the economic activity in the business centres of America during the first half of the $19^{\text {th }}$ century. ${ }^{35}$

\section{Railroad Analysis: Connecticut}

\section{Observations:}

Connecticut data from 1837 to 1869 show that the average post-master compensation in railroad towns is consistently higher than the postmaster compensation in the state as a whole. Between 1837- 1843 the compensation average for railroad towns steadily increases, going from $\$ 376.30$ to $\$ 730.16$. Between 1843 and 1845 railway town postmaster compensation fell from $\$ 730.16$ to $\$ 560.17$. In the data slot for 1837 we added railroad towns with compensation levels lower than the rail towns already in the sample. This lowered the railroad town compensation average. In the decade between 1849 and 1859 there is quite a bit of volatility in the railroad town compensation averages. From 1849 to 1851 railroad town averages increase by $\$ 222.24$. However, in 1851 it drops to $\$ 574.78$, and then increases over the next 8 years to $\$ 980.42$ in 1859. In the next decade the average compensation for railroad towns reaches a high of $\$ 1596.86$, and then drops to $\$ 842.37$ in 1869 .

While the all-state compensation averages are a substantially lower than railroad towns, the rate of changes is quite comparable. Between 1837 and 1843 the compensation average for the state steadily increases, going from $\$ 108.04$ to $\$ 157.37$. The rate of change, similar to railroad towns, goes up with a high in 1843 of $20.95 \%$. There is a drastic drop in 1845 from $\$ 157.37$ to $\$ 89.90$, a rate of change of $-42.87 \%$. From $1847-1857$ there is a steady increase in the Connecticut postmaster compensation averages, apart from a drop in 1853 to $\$ 109.93$, a change of -27.29\%. From 1861-1869 there are increases in the state average. Between 1861 and 1863, the increase is from $\$ 166.81$ to $\$ 216.44$. The all-time high in state average compensation is \$259.46 in 1867 .

In railroad towns the per capita postmaster compensation shows a steady increase from $\$ 0.008917$ in 1837 to a high of $\$ 0.016422$ in 1843 . This is a rate of change of $40.14 \%$. However, from 1843 to 1869 , while there are temporary increases, there is a general decline. Between 1843 and 1847 there is a decline from $\$ 0.016422$ to $\$ 0.011724$. Despite an increase in 1849 to $\$ 0.014220$, shortly after in 1851 there is a drop to $\$ 0.007657$. In this two year period, from $1849-1851$ there, is a $-45.15 \%$ rate of change. Between 1853 and 1869 the railroad town per

\footnotetext{
${ }^{35}$ See Chart 1 and Figures 4 and 5 for data on the Prewar U.S. industrial economy and for more graphs on per capita changes in Massachusetts.
} 
DIMAND, HINES, GONG, O'REILLY, VELK, ZHAO $19^{\text {th }}$ Century Economic Activity

capita postmaster compensation never goes above 0.01 and reaches the lowest value of $\$ 0.003561$ in 1869 .

The all-state per capita postmaster compensation rate of change fluctuates in the same way as it does in the railroads town. Along the all-state per capita postmaster compensation timeline, there is a steady increase from $\$ 0.00036$ in 1837 to $\$ 0.00051$ in 1843 . This is a rate of change of $20.95 \%$. Just as we saw in the railroad per capita compensation picture, there is a decline in 1845 to a low of $\$ 0.00029$. The state average per capita compensation does increase however. It reaches $\$ 0.00050$ in 1857 , drops to $\$ 0.00036$ in 1861 . Thereafter it increases, finishing at $\$ 0.00054$ in 1869 . The highest per capita value is in $1865-1867$, when it reaches a value of $\$ 0.00056$.

\section{Analysis:}

We use Postmaster compensation paid in Connecticut towns, some with railroads, and some without, to measure economic activity. We see how the national business cycle affects Connecticut railroad towns versus the impact on Connecticut towns in general. In 1837 there are two railroad towns in Connecticut that have an average compensation of $\$ 376.30$. This is higher than the state average of $\$ 108.04$. In 1837 , railroad compensation increased to $\$ 410.08$, for an $8.98 \%$ improvement. From 1837 to 1843 , there is a steady upward trend in the railroad compensation average, which is shown by the positive rates of change present in each year (Figure 7). Despite the Panic of 1837 occurring, which resulted in widespread bank failures and unemployment, both state level and railroad compensations improved until $1843 .^{36}$ The rates of change in 1841 signify a Connecticut compensation average improvement of $27.05 \%$ for railroad towns in comparison to $7.40 \%$ for the state. This was followed by even further increases in compensation averages of $40.14 \%$ in 1843 for railroad towns, while the state improved by 20.95\% (Graph 9).

This large increase in compensation averages may come as a result of a business cycle that occurred from 1843 to $1845 .{ }^{37}$

Compensation averages experienced a sharp decline of $-23.28 \%$ and $-42.87 \%$ in the year 1845 for both railroad towns and the state, respectively (Graph 9). This dip likely occurred as a result of the recession that took place. The economic contraction in 1845 was considered moderate, however conditions that likely would have resulted in a depression may have been mitigated when government expenditure for the Mexican War revived business activity in

\footnotetext{
36 “1830 Fast Facts," United States Census Bureau. Accessed March 31 2015. https://www.census.gov/history/www/through the decades/fast facts/1830 fast facts.html.

37 NBER. "US Business Cycle Expansions and Contractions." Accessed March 31, 2015. http://www.nber.org/cycles/cyclesmain.html.
} 
Graph 9

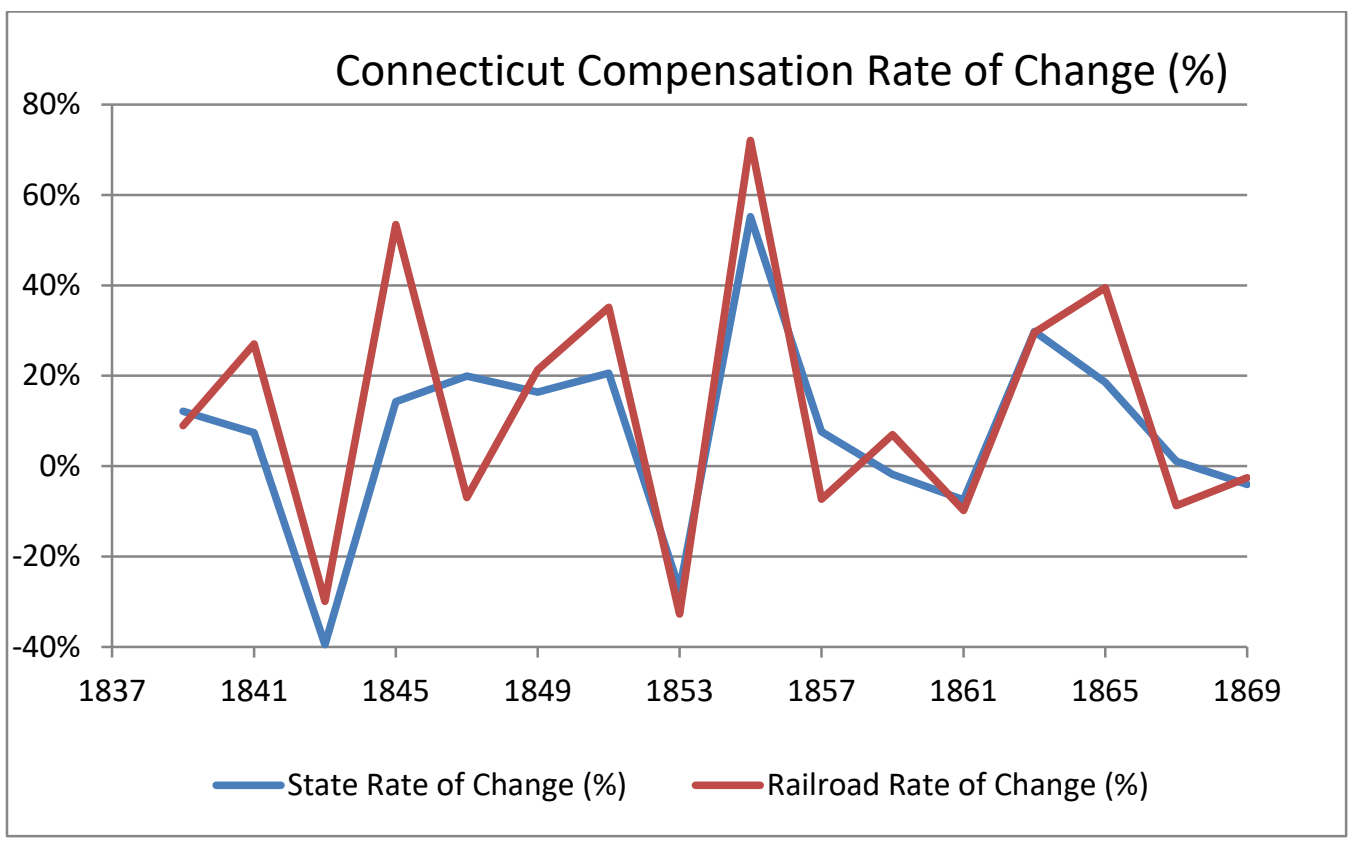

$1846 .{ }^{38}$ Following 1845 , the compensation averages made improvements, as displayed by the rates of change, and from 1847 to 1851 there was a large increase in the railroad compensation average while the state average improved by a lesser degree. By 1851, state and railroad compensation averages had improved by $20.57 \%$ and $35.15 \%$, respectively, with the railroad average reaching a new high of $\$ 854.48$ (Graphs 9, 10). The improvements Connecticut experienced from 1847 to 1851 can likely be attributed to the business cycle that occurred in $1847 .{ }^{39}$

In 1853 , interest rates rose and security prices fell. This was largely due to the recession. One can see the impact of the recession through the decline of business activity, which dropped by $19.7 \%$. The impact of the recession on the towns one can also see through the decreased railroad construction mileage in this year. ${ }^{40}$ The Connecticut postmaster compensation data also shows the recession. For example, railroad and state compensation averages dropped by

\footnotetext{
${ }^{38}$ Victor Zarnowitz (1992): 222, http://www.nber.org/chapters/c10378.pdf. Accessed March 31, 2015.

39 NBER. "US Business Cycle Expansions and Contractions." Accessed March 31, 2015. http://www.nber.org/cycles/cyclesmain.html.

${ }^{40}$ Zarnowitz (1992): 223.
} 
DIMAND, HINES, GONG, O’REILLY, VELK, ZHAO $19^{\text {th }}$ Century Economic Activity

Graph 10

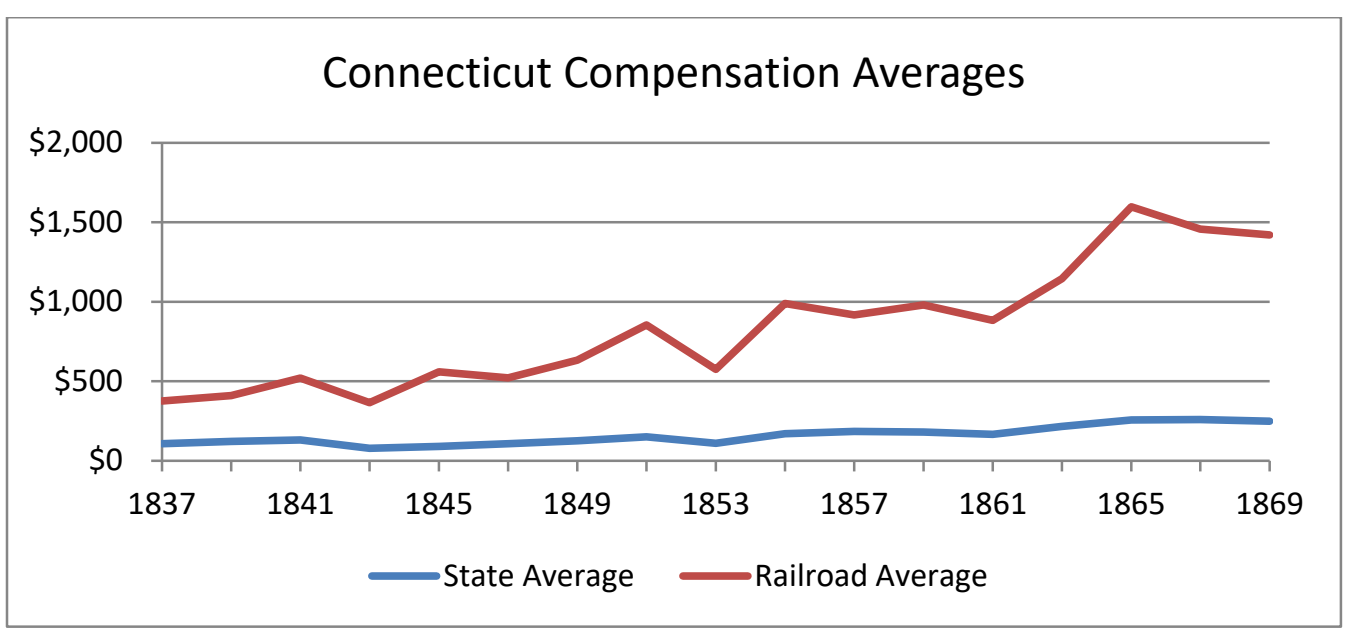

$-32.73 \%$ and $-27.29 \%$ (Graph 9). The state average compensation dropped from $\$ 151.19$ in 1851 to $\$ 109.93$ in 1853 (Graph 10).

One might also be able to explain the compensation decline through another event other than the recession. 1853 experienced the Norwalk Rail Accident, which occurred on the New York and New Haven Railroad line. This incident claimed the lives of at least 40 people. ${ }^{41}$ A disaster of this sort may have caused widespread panic regarding the use of trains, which could have resulted in less travel to railroad towns. This could help explain why the railroad compensation average dropped over 5\% more than the state average during the recession, as shown in the rate of change data for 1853 (Graph 9).

Following the recession, in 1854, the physical volume of domestic trade increased around $5 \%{ }^{42}$ This economic improvement likely enabled a recovery effort and further growth into 1855 that is represented in the data. The compensation average for Connecticut and railroad towns reached all-time highs of $\$ 170.78$ and $\$ 989.07$, respectively (Graph 10). The rates of change show the compensation average improvements, as the state level average increased by $55.17 \%$ while the railroad average increased by $72.08 \%$. However, the peak in 1855 was short lived as the state compensation average improvements slowed, increasing by only $7.63 \%$ in 1857, which was later followed by a decline of $-7.44 \%$ in 1861 (Graph 9). The state and railroad compensation averages show some volatility through this period, however it is quite minimal.

41 Emma Demar and Elizabeth J. Normen (2011). Accessed March 31, 2015: http://connecticutexplored.org/wordpress/wp-content/uploads/2011/11/Disaster-Fall-2011.pdf.

${ }^{42}$ Zarnowitz (1992): 223. 
The slowed growth in compensation can be linked to the recession of 1857/1858 and $1861 .{ }^{43}$ The railroad compensation averages resemble these recessionary periods, as they declined in 1857 and improved in 1859 , only to decrease once again in 1861, which is indicated in the rates of change (Graphs 9, 10).

The start of the Civil War also marked the beginning of a business cycle that went from 1861 to its peak in $1865 .{ }^{44}$ This period marked substantial growth for railroad towns with the average compensation improving from $\$ 884.06$ in 1861 to $\$ 1596.86$ in 1865 . During this time, the railroad compensation average had declined $-9.83 \%$ in 1861 , which was followed by sizeable improvements of $29.54 \%$ in 1863 , and $39.44 \%$ in 1865 (Graphs 9, 10). The state compensation average rates of change closely resembled the railroad rates of change up until 1865 , where the state average experienced an $18.58 \%$ increase in comparison to the $39.44 \%$ improvement in the railroad average. These improvements in railroad town compensation might be a result of Connecticut having recently completed 601 miles of railroad. ${ }^{45}$ The Consolidated, otherwise known as the New Haven, became the dominant railway company by $1872 .{ }^{46}$ This was a highly profitable enterprise that increased business substantially in railroad towns.

In 1867, the United States of America went through another recessionary period. ${ }^{47}$ Again, the Connecticut state and railroad town data show the effects of the recession as the compensation averages only improved by $1.09 \%$ on the state level while the railroad average fell by $-8.75 \%$. This decline worsened in 1869 as the compensation averages dropped by $-4.02 \%$ at the state level and railroad averages dropped by $-2.54 \%$ (Graph 9). In 1869, there was also a mild contraction in economic activity, however it was short-lived. This downturn in the economy came at the same time as the greatest acceleration in railroad investment. This recession may have occurred because of below-average growth as opposed to an actual decline of cyclical proportions. ${ }^{48}$ It may be possible that the large increase in Connecticut state and railroad town compensations from 1861 to 1865 came as a result of their involvement in the Civil War. Connecticut arms manufacturers had become some of the best firearms producers in the country, and by the end of the war, they had supplied around $43 \%$ of all weapons bought

\footnotetext{
${ }^{43}$ Zarnowitz (1992): 223.

${ }^{44}$ Davis (2006).

${ }^{45}$ Thies (2002): 253. Accessed March 31, 2015.

http://object.cato.org/sites/cato.org/files/serials/files/cato-journal/2002/11/cj22n2-4.pdf.

46 "New York, New Haven \& Hartford Railroad Small Format Photograph and Postcard

Collection," Thomas J. Dodd Research Center, University of Connecticut Libraries. Accessed 31

March 2015. http://doddcenter.uconn.edu/asc/findaids/NHRR_Smallformat/MSS19910133.html.

${ }^{47}$ Zarnowitz (1992): 223

${ }^{48}$ Zarnowitz (1992): 223.
} 
DIMAND, HINES, GONG, O'REILLY, VELK, ZHAO $19^{\text {th }}$ Century Economic Activity

by the War Department, most of which went to the Union Army. ${ }^{49}$ The states involvement in the war may have improved the economy as well as boosted postal mail. However, upon completion of the war, with soldiers returning home and a lower demand for weapons, the economy of Connecticut likely experienced a slight downturn, which could account for the decline in the compensation averages as shown through the rates of change for both the state and railroad towns (Graph 9).

In conclusion, the compensation averages for Connecticut experienced some volatility throughout the period of 1837 to 1869 , however both state and railroad town averages experienced an overall upward trend. Our data shows that the railroad towns had significantly more volatility, but this may be a result of the way our data was collected. In the earlier years, there are far fewer sample towns than in the final year of the data set; namely, we increase from 2 in 1837 to 25 in 1869 for Connecticut. This can account for the extreme volatility of the railroad income per capita in the earlier years. As more towns are added, the income per capita trends downward, moving slightly closer to the state income per capita levels. From our data, it is clearly recognized that railroad towns have postmasters receiving higher compensations, but this is in line with our argument, as railroads served as a connecting force for larger towns that were of higher economic importance to the state (Graph 10) When comparing the graphs of both the state and railroad towns, it can be observed that railroad towns are typically more responsive to business cycles and historical events, as the peaks and troughs tend to be more extreme. Many of the business cycles and recessionary periods in the $19^{\text {th }}$ century are shown to have effects on the postmaster data. As such, postmaster compensation for the state of Connecticut appears to be a useful data sample for analyzing economic activity in the $1800 \mathrm{~s} .{ }^{50}$

\section{Railroad Analysis: Maine}

\section{Observations:}

In the state of Maine, the average compensation of the railroad towns are higher than the average compensation for the aggregate of all towns in the state. This can be illustrated from the graph shown below (Graph 11) which runs from 1841 to 1869 .

This is not surprising since the railroad town average contains major economic towns such as Portland or Bangor (the latter was considered to be the "Lumber capital of the world" 51 in the 1800s). There were 26 towns that were picked for the railroad towns. Included were all the starting towns, ending towns and three middle towns along the railroads. (A starting town is the town where route construction was initiated, a middle town was more or less half way along

\footnotetext{
${ }^{49}$ Nelson, Dean. "Connecticut Arms the Union," Connecticut Explored 9, no. 2 (2011): 30-37.

${ }^{50}$ See Figures 6, 7, and 8 in the appendix for further graphs on per capita rates in Connecticut.

51 "Bangor, Maine: History." Bangor, Maine: History. Accessed April 6, 2015. http://bangorinfo.com/history.html.
} 


\section{Graph 11}

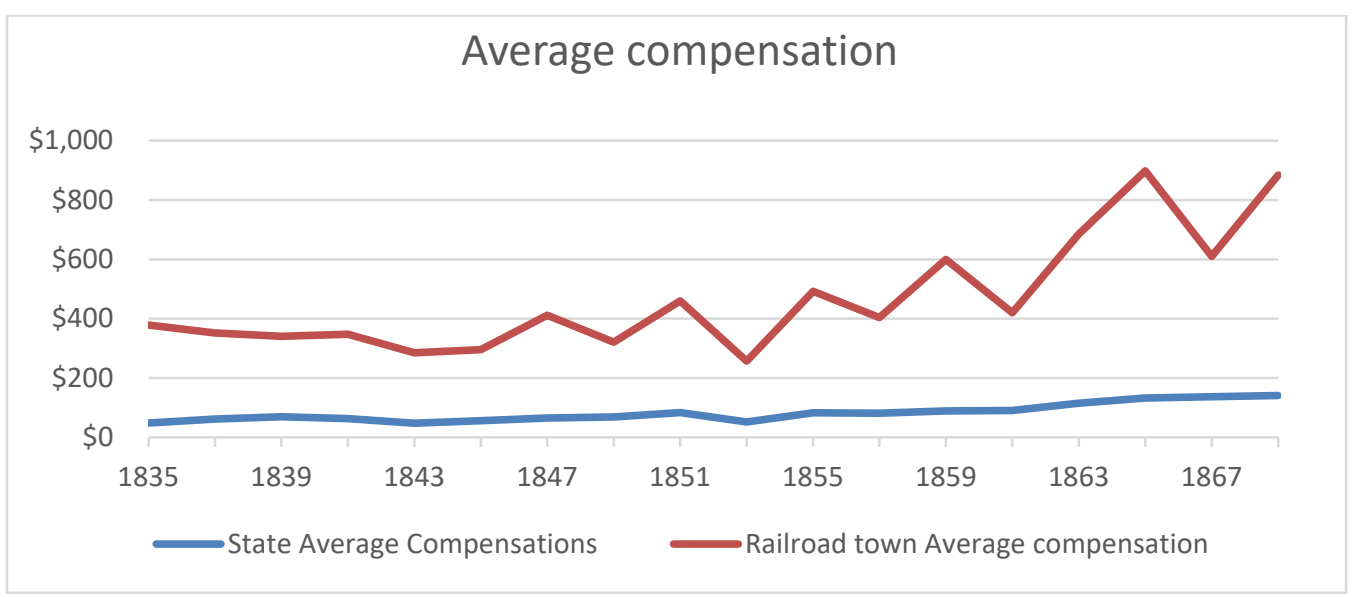

the route, and the end town marked the end of the route, as completed. Of course, later on many small routes were grouped into larger aggregated railway systems.)

There is higher volatility in the graph representing the average compensation for the railroad towns than the graph representing the average compensation for the all-state towns. We tried to smooth out the volatility of the railroad towns by taking a larger sample number of railroad towns.

We see a trend in the two graphs above. The two graphs seem to show a gradual increase in the average compensation. The average compensation has a small peak at 1843 and falls after 1845. Furthermore, there seems to be a trough in the two graphs around 1853. This suggest a fall in economic activity (that will be analyzed in the next section.) The average compensation also increases gradually after 1835 with steep rise after 1861 . This bump-up could be explained by the beginning of the Civil War. The graph for the average compensation for railroad towns falls after peaking at 1865 . It seems the War's end disproportionately affected the railroad towns in the short run: average compensation for the railroad towns quickly recovers, and resumes its $g$ increase at, if anything, a slightly greater pace.

The graph for average postmaster compensation (Graph 11, railroad towns versus all-state towns) shows high volatility in the railroad town data. After each temporary increase, there is a fall-back, albeit to a rising trend. The two graphs have very similar pattern, although the graph for postmaster payments in the railroad towns is more volatile than the baseline rate of change for all-state towns. In 1855 the graphs of the rate of change of the railroad towns and the allstate towns have a peak with an increase of more than $50 \%$ for the state towns and around $90 \%$ increase for the railroad towns (Graph 12). This is analyzed more thoroughly in the next section. 
DIMAND, HINES, GONG, O'REILLY, VELK, ZHAO $19^{\text {th }}$ Century Economic Activity

Graph 12

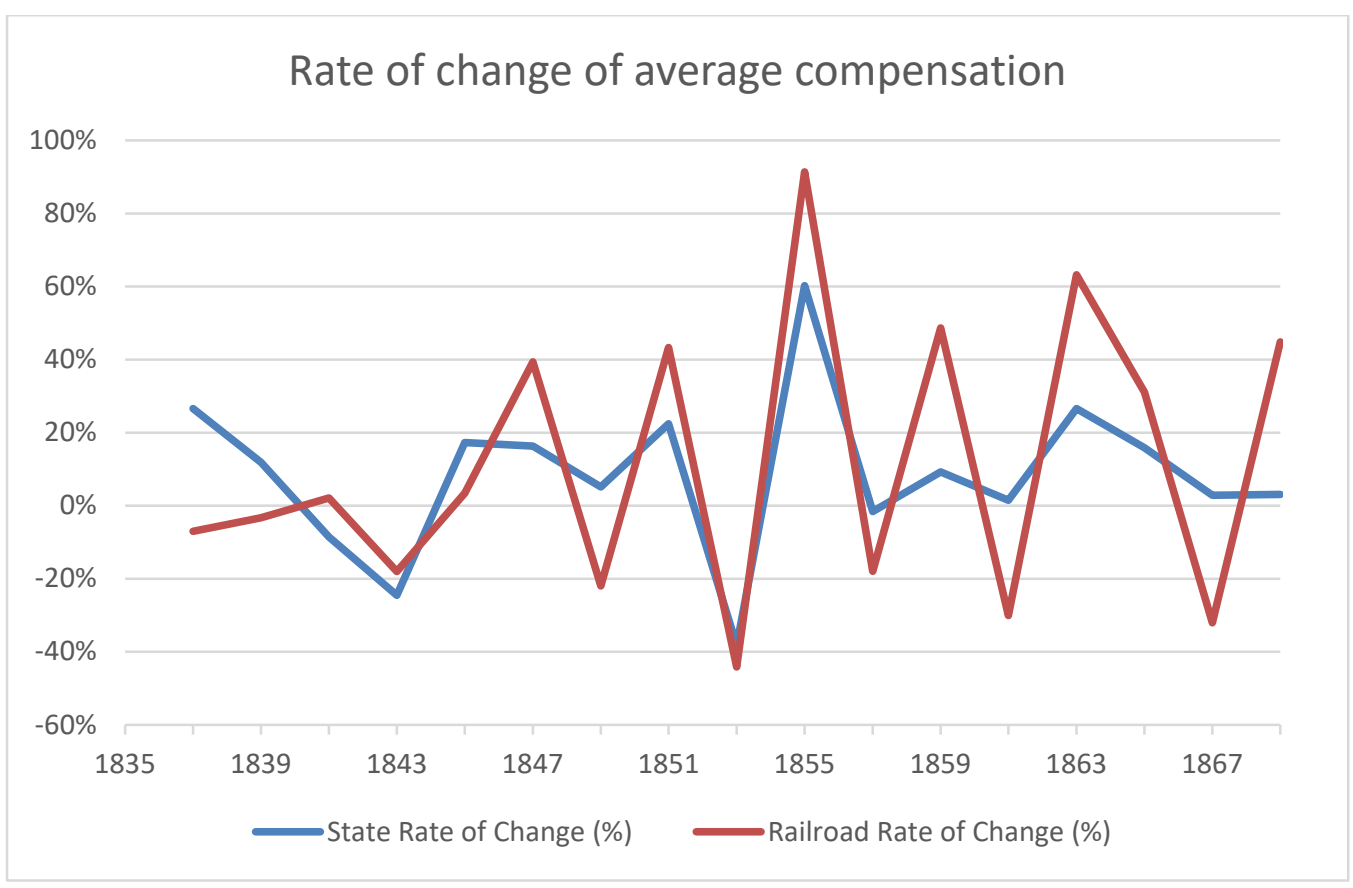

Limitations:

Our study has its imperfections. Firstly, we used the average compensation of all towns in the state as the baseline irrespective if they were a railroad town or not. The analysis on the impact of the railroad towns would have been better if the average compensation of railroad towns were done against average compensation of non-railroad towns. That is the baseline should consist of average compensation of towns where the railroads did not pass. It was however very difficult and tedious to identify all the non-railroad towns (some towns became railroad towns, some towns were in close proximity to railroad towns, some towns were on complex railroad routes, but not included by us in the sub-set of route towns) from the ones with rail roads. Secondly, only 24-26 towns were used to compute the average compensation of railroad towns. We recognize that using all towns would have made the analysis more accurate and reliable but the task would have been taken us well beyond the time constraint presented by the schedule for this paper. We realized that the sample size chosen was enough to help reduce some volatility in the numbers. Thirdly, the average compensation of postmaster was available only for every two years. There could have caused some smoothing in the trend of our graphs. Given all these limitations, we still tried to make the best inferences and analysis from the data we did gather. 


\section{Analysis:}

We here present links between our data, which is at a state and local level, and various macroeconomic shocks and major historical events that took place during our time frame. In the state of Maine do macroeconomic shocks or external events explain the trend and fluctuations in the all-state average postmaster compensation? Are there disproportionate effects on the average compensation in our sample of railroad towns?

The average postmaster compensation in railroad towns is higher than the baseline state average. We conclude there was higher economic activity in railroad towns as compared to the average towns in the state. It is likely that towns through which a railroad passed allowed trade, agricultural and nascent industry to proceed at low transportation cost. Bangor and Portland were economic hubs. They had a proportionately greater mail volume than did lesser towns. That mail volume translates to higher compensation for the postmaster.

\section{Analysis of business cycles and historical events:}

Using NBER business cycle dates, we see that some of the troughs and peaks identified by the National Bureau of Economic Research (NBER) correspond to the same peaks and troughs that are identified in our two sets of data. For instance, in 1861 NBER identifies a trough that matches the fall in average compensation for both the all-state and the railroad towns. It seems that, for Maine, the state average compensation data reflects on a micro level the national business cycle.

\section{Graph 13}

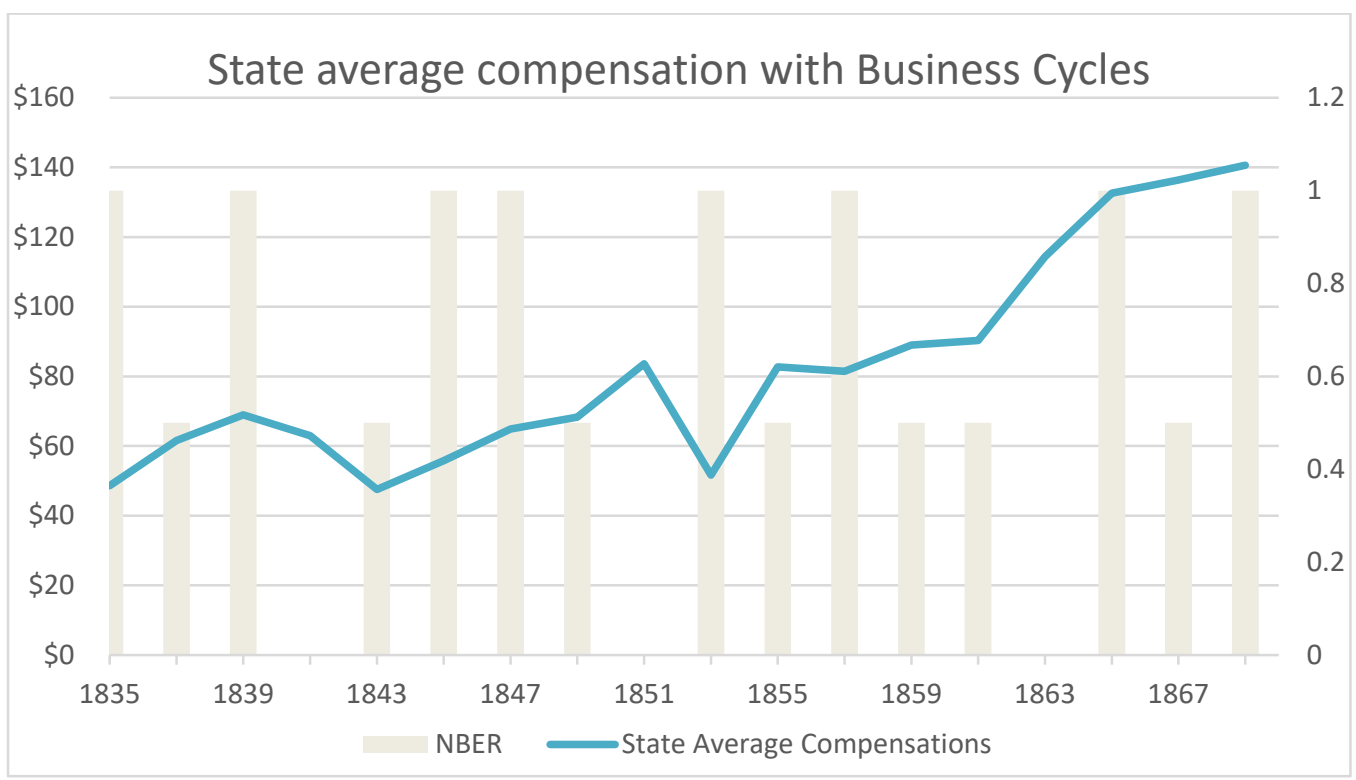


DIMAND, HINES, GONG, O’REILLY, VELK, ZHAO $19^{\text {th }}$ Century Economic Activity

\section{Graph 14}

\section{Average compensation of Railroad town with Business Cycle}

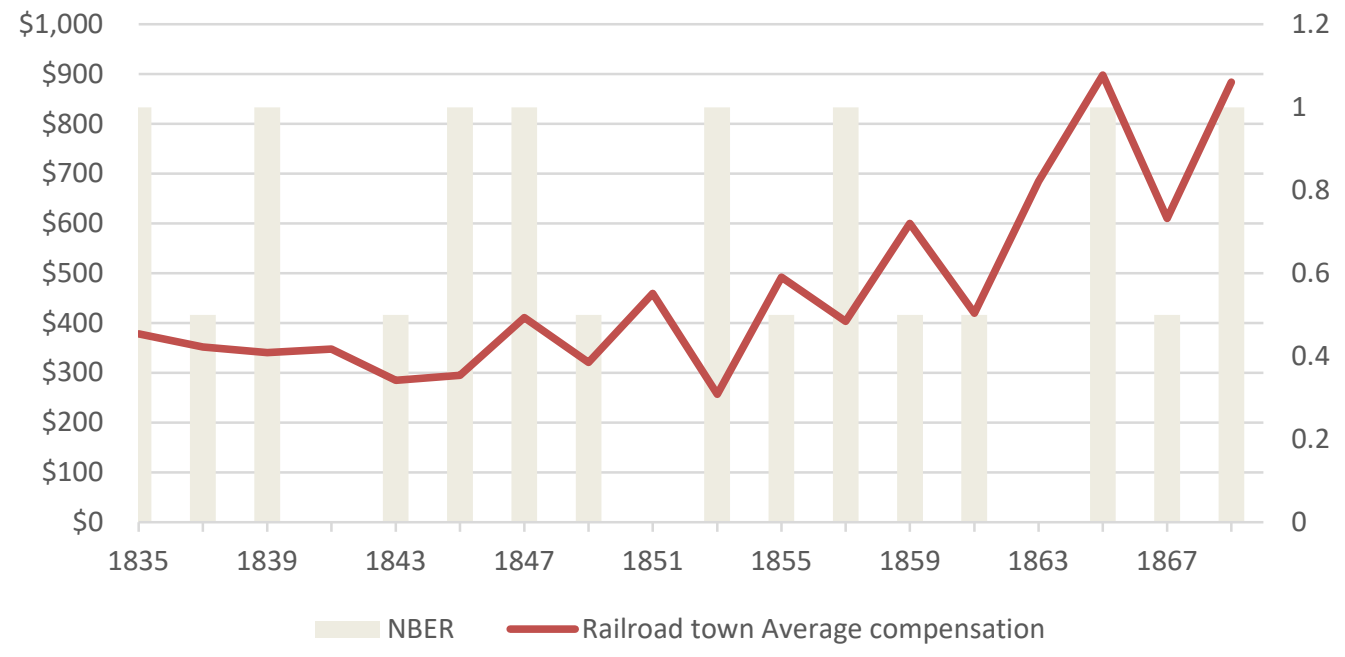

The two graphs above show the average compensation for the railroad towns, the state average compensation and the peaks and troughs identified by the National Bureau of Economic Research (NBER). The grey bars at 1 show a peak and those at 0.5 show a trough as identified by the NBER. The orange graph appears to better match the business cycle than the blue graph. For example, the graph for the average compensation for the railroad towns clearly match the trough identified by the NBER in the years 1849 and 1869, while those are not seen in the graph for the state average compensation.

It is also interesting to note that the business cycles identified by the NBER have some discrepancies with the ones identified in the graph of state average compensation and the average compensation of the railroad towns. As an example, the graph in figure C clearly shows a local peak at 1843 which was a year where NBER identified that there was a trough at this time period. Those figures could be explained by other historical events or shocks that affected the state of Maine. The analysis will now be done on the different historical events that could affect the state average compensation in the state of Maine.

The two graphs above show an increase in average compensation from 1841 to 1843 . This rise in state average compensation and the average compensation of postmasters in railroad 
towns could be linked to the end of the Aroostook war. This war was a dispute that took place along the Maine-New Brunswick border. The Webster-Ashburton Treaty was signed in $1842^{52}$ to end the border issues. The treaty ended the confrontations and the uncertainty that those conflicts posed to the booming lumber industry in northern Maine ${ }^{53}$. Although there was a trough at this time period on the national level, on a micro-State level the benefits of this treaty might have led to higher economic activity measured by higher mail volume and higher average postmaster compensation.

The potato famine of 1845-1851 "triggered a dramatic increase in migration" 54 of families from Ireland to the state of Maine. This migration contributed to a $16 \%$ (refer to appendix) increase in the population of Maine between 1840 and 1850. This was a greater population increase than the $7.74 \%$ increase between 1850 and 1860 . The state average compensation did rise steadily over the entire time period. It could be inferred that the mass migration of Irish families played a role in higher aggregate economic activity in Maine. Whether or not that translated into higher per capita income for the general population is not clear. The influx of migrants likely increased the volume of mail in those towns and consequently led to higher average postmaster compensation.

The trough identified in 1853 in both the two graphs is not consistent with the peak identified on a macroeconomic level by the NBER. We are thinking about how we may explain this issue.

The data from the state average compensation and the average compensation for the railroad towns show a decline at the beginning of the Civil War in 1861. The NBER recognizes this slowdown. It can be seen that the decline is more extreme in the graph for the average compensation for the railroad towns than the state average compensation (refer to Graph 12). Perhaps the onset of war (Maine's warriors played an important part, most conspicuously at Gettysburg) and early uncertainty about its outcome affected economic activity to an equal extent locally and nationally. Between 1861 and 1863 there was a steeper rise in postmaster compensation in the railroad towns than in the baseline towns.

State of Maine data shows that the railroad towns on average had more economic activity than the baseline average of all towns in the state. This is shown by the higher average compensation for the postmaster for all the years we collected data. We also saw how the allstate average compensation for postmasters gives evidence, at state and local level, in support

\footnotetext{
52 "Webster-Ashburton Treaty | United States-United Kingdom [1842]." Encyclopedia Britannica Online. Accessed April 6, 2015. http://www.britannica.com/EBchecked/topic/638660/Webster-AshburtonTreaty.

53 "Webster-Ashburton Treaty, 1842 - 1830-1860 - Milestones - Office of the Historian." WebsterAshburton Treaty, 1842 - 1830-1860 - Milestones - Office of the Historian. Accessed April 6, 2015. https://history.state.gov/milestones/1830-1860/webster-treaty.

54 "Maine History Online." - 1820-1850 A New State \& Prosperity. Accessed April 6, 2015. https://www.mainememory.net/sitebuilder/site/901/page/1312/print.
} 
DIMAND, HINES, GONG, O'REILLY, VELK, ZHAO $19^{\text {th }}$ Century Economic Activity

of the macroeconomic business cycle dates as identified by the NBER. Our business cycle dates sometimes differ from those of the NBER. We explain the difference by historical events that took place at the sub-national level, in the state of Maine. Lastly, we also saw that the cycle peaks and troughs were more extreme for the average compensation for railroad town postmasters than for the state average.

\section{Railroad Analysis: Vermont}

\section{Observations:}

Average compensation:

Graph 15 shows the average postmaster compensation for the all the towns, railroad and nonrailroad, in the state of Vermont compared to the average postmaster compensation for Vermont railroad towns.

Average compensation for both all-state and railroad towns trend upward through 1843 to 1869. When looking at the data, it is also important to note that throughout this time period there were more railroads constructed. We claim the extra growth which followed gave an extra boost to the average postmaster compensation for railroad towns. When looking at the all-state average postmaster compensation, it is important to note that the data encompasses both railroad and non-railroad towns in the all-state average. One of the reasons for doing so is that

\section{Graph 15}

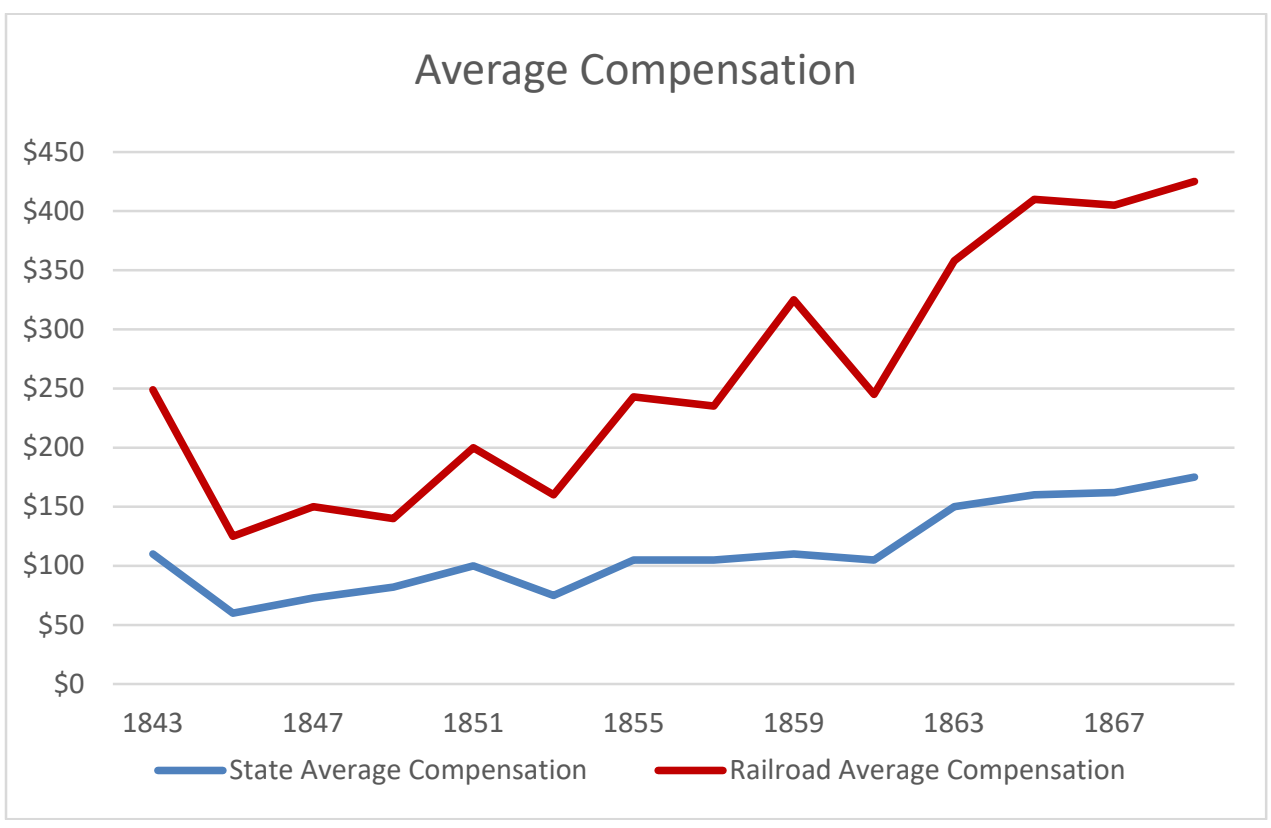


we do not have data that inclusively identifies every single railroad town. Therefore, our allstate numbers would necessarily include at least some towns actually having rail service, although that particular railroad would not be known to us.

The data also demonstrates a drop in state average and railroad average compensation during 1853. Average compensation for state and railroad towns increased after 1853 until 1859. However, there is a small drop in compensation in 1857.

We observe that railroad town average compensation decreased in the early sixties then increased (from $\$ 236$ to $\$ 416$ ) through 1861 to 1865 . During the same period, average state compensation decreased and then increased again during the late sixties.

Furthermore, average compensation for railroad towns is higher than the average compensation for the all-state towns. It is clear that railroad towns have more intense economic activity. The average compensation for railroad towns ranged from $\$ 140$ to $\$ 440$. All- state average compensation ranged from $\$ 60$ to $\$ 190$.

\section{Rate of change for average compensation:}

Graph 16 shows the rate of change in average compensation for railroad towns compared to the rate of change in average compensation for all-state Vermont towns.

\section{Graph 16}

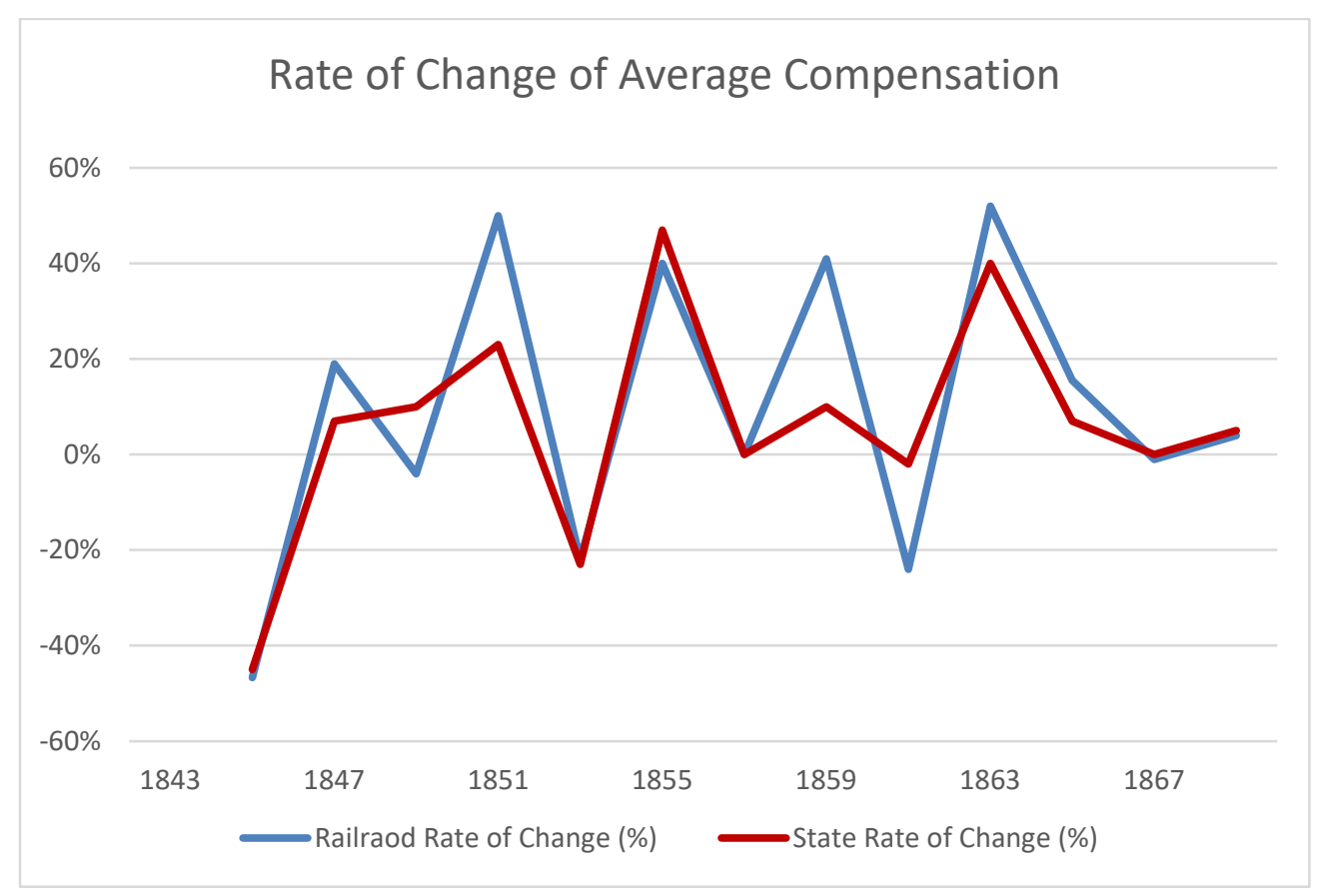


DIMAND, HINES, GONG, O'REILLY, VELK, ZHAO $19^{\text {th }}$ Century Economic Activity

The data is volatile: especially so for railroad towns between 1861 and 1863 (53\% change). The major all-state town fluctuation we uncovered occurred between 1853 to 1855 (50\% change). This jump was higher than the change in railroad average compensation for the same interval.

In the period between 1843 and 1869, the volatility in the rate of change for all-state average compensation is lower than the volatility in the rate of change for railroad towns' compensation. The magnitude of change in average compensation for railroad towns is greater than the size of change in state compensation. Between 1857 and 1859 the rate of change was $44 \%$ for the railroad town compensation and only $10 \%$ for the state compensation.

\section{Analysis:}

We compared our state and railroad average compensation data with the NBER business cycle data to see if there is any correlation between average compensation and business cycles through the period of 1843 to 1869 . We were able to witness how all there was lots of growth and progress in the $19^{\text {th }} \mathrm{C}$. Our data demonstrates this, since average all-state compensation and railroad towns' also increase. As already mentioned, many Vermont railroad routes were built between 1843 to 1869 . This is most likely a response to increased general economic activity in the state of Vermont; especially so in towns where railroads connected the once isolated state with the rest of New England.

In 1843 there is a decrease in average compensation for the state and for railroad towns. According to NBER data, there was a recession in 1843. Rising Vermont postmaster compensation numbers for the all-state and railroad towns from 1845 to 1851 supports the idea that the NBER's national "boom" was felt up North. ${ }^{55}$

Before the 1840s Vermont was one of the slowest growing states. Our data, that shows decreasing average compensation during 1843, supports this view. However, after the early 1840 's the population of the state increased through immigration, some of it from Canada. ${ }^{56}$ Many French Canadians arrived in Vermont looking for work. ${ }^{57}$ In one of our earlier essays, we showed how French Canadians and Irish persons, quite possibly entering from Canada, appeared early on in lists of postmaster names. Irish names appeared in southern Vermont too, suggesting that immigration occurred along railroad lines up from Boston and down from Montreal. This immigration process is mentioned later on in this essay.

According to Elise Guyette (1992), ${ }^{58}$ the first railroad that was constructed in Vermont was built in the early 1840s. This event may have caused the increase in average compensation for

\footnotetext{
${ }^{55}$ Davis (2006).

56 Guyette (1992). Accessed $31 \quad$ March 2015 from http://www.flowofhistory.org/themes/movement_settlement/immigration.php.

${ }^{57}$ Claude Bélanger (1999).

${ }^{58}$ Guyette (1992).
} 
the state and an even higher increase in compensation for railroad towns. This increase in average railroad towns' compensation was a result of an increased volume of mail passing through railroad towns. At the same time more people immigrated to Vermont in order to work in different industries and rebuild farms. ${ }^{59}$ These events may explain the increase in average compensation from between 1844 and 1851.

For 1853 and 1854 there is a decrease in average compensation for both the state and railroad towns. Some scholars observe a national boom during these years. ${ }^{60}$ According to the NBER data a recession hit the United States late in 1854 . We see the slowdown occurring earlier because our micro data is (perhaps) more sensitive to change. Macro level national events might also take longer to register on the NBER's economic barometer. In any case, our data shows how in Vermont, average postmaster compensation falls before the NBER announces the recession; indeed we show a slowdown while the macro data suggests continued prosperity ${ }^{61}$

Postmaster compensation moves up for the state and railroad towns from 1855 to 1860 . This is consistent with the standard view that this time period was prosperous for state development. ${ }^{62}$ Though our data largely agrees with this hypothesis, it is able to identify key time periods where there was some economic slowdown. 1858 is such a year where this national slowdown is evident. This slowdown is associated with a financial panic brought on by declining international traffic and foreign trade restrictions along with "over exuberance" in the American domestic economy ${ }^{63}$ Our (more sensitive) data for average compensation dropped in 1857. We anticipate the "official" recession start date. Perhaps the more microeconomic numbers we have may detect business cycles at their very earliest appearance.

In 1861, with the start of Civil War there is also a drop in compensations, matched by an "official" recession in the national economy. ${ }^{64}$ This drop was greater than the previous decline during 1853. The War however induced more disruption than did the recession. During each drop or increase in all-state average compensation there is a similar fluctuation in railroad towns' average compensation. However the change in railroad town compensation is always greater than the change in all-state compensation.

There is a general increase in compensations for the state and railroads towns from 1862 to 1869 with a small drop in 1867 . During the same period we can see the same pattern in the NBER data. They date a "boom" in 1864 and in $1869 .{ }^{65}$ Some scholars suggest a recession in

\footnotetext{
${ }^{59}$ Guyette (1992).

${ }^{60}$ Davis (2006).

${ }^{61}$ NBER data.

${ }^{62}$ Davis (2006).

${ }^{63}$ Willard Thorp (1926).

${ }^{64}$ Davis (2006).

${ }^{65}$ Davis (2006).
} 
DIMAND, HINES, GONG, O'REILLY, VELK, ZHAO $19^{\text {th }}$ Century Economic Activity

1867; this recession matches the slight decrease in compensation during the same year. This recession was associated with decreased foreign trade and increased domestic unemployment. ${ }^{66}$

Finally, the increase in average railroad towns' compensation after 1863 was partly due to the then-rapid expansion of Vermont's railroad system: it became better linked to national systems, resulting in more exports and higher local income. ${ }^{67}$

\section{Names Analysis}

\section{Objective:}

From the postmaster compensation data for New Hampshire, Vermont, Massachusetts, Pennsylvania, and New York, we extracted the dates, names, towns, and compensation amounts for those postmasters. Our main objective was to identify the ethnicities of the people who had received compensation from the government as postmasters. We believe that ethnicity data will allow us to better study the demographics of the population at local and town level. We use it to study immigration demographics at the micro level. Our working thesis was that postmasters would be either descendants of the Mayflower, Irish, or English protestant ancestors. Though many postmasters had English and Irish roots, the research revealed that a large number were of other European origin.

\section{Methodology:}

\section{Tools:}

We used the database genealogy.com to determine the ethnicity of each person's surname. We found this website to be quite useful, as it provided multiple origins for each surname. The database most of the time was able to determine if the name was an "Americanization" or translation of a surname, and whether or not it was a variant of a more common surname.

\section{Restrictions:}

The biggest restriction that limited our research were names that were unidentifiable. Due to time restrictions, we created research parameters so that we could be more efficient in our work. Some names could not be traced on genealogy.com. Most of the time, we believe this to be a result of errors in spelling either by the initial document, or by those who transcribed the initial documents into the dataset. Usually we were able to infer the origin of the "unknown" name, but we chose to keep its "unknown" label so as to not collet incorrect data. Another unfortunate

\footnotetext{
${ }^{66}$ Thorp (1926).

${ }^{67}$ Parsons, Graham. "Picturing the Past." Accessed March 31, 2015.

http://www.images.technomuses.ca/?en/stories/central vermont/b/page/1.
} 
restriction is that some of the compensation data was omitted, therefore making it more difficult to examine averages, maximum and minimum compensations per ethnicity.

\section{Conclusion:}

Our postal work in its entirety is intended to open the door to a valuable research tool, and so enable others, more skillful than we, to benefit from what we have called this "data goldmine" of the Official Register. We believe that determining the ethnicities of postmasters in the United States will be an insightful tool for those who wish to do a better study of the topic. We will answer this question: which ethnic groups, other than Anglo-Irish were able to improve their economic, political and even social status by way of postal employment? We will also discover the timing for "upward mobility", as the waves of $19^{\text {th }}$ Century immigrants "climbed the ladder" to a Presidential appointment as postmaster.

\section{New Hampshire:}

\section{Observations:}

New Hampshire postmaster names were split into parts: 1816 - 1845 and 1847 - 1869. This was because we were given new data with more years of documented compensation after the initial data had been examined.

\section{6-1845}

For the data from New Hampshire from 1816-1845, the average pay for all postmasters was $\$ 71.75$. The maximum price for all of the names was $\$ 2,907.20$. The minimum amount paid for all of the names was $\$ 0.19$.

For Irish names, the maximum amount of compensation was $\$ 847.04$. The minimum amount of compensation was $\$ 0.43$. The average amount of compensation was $\$ 70.46$, just less than the average of all of the names.

For the Mayflower names, the average amount of compensation was $\$ 88.56$. This is considerably more than the overall average. In fact, they had some of the highest rates of compensation. Though their highest amount of compensation was relatively low at only $\$ 903.64$, their lowest amount of compensation was relatively high. The lowest paid rate of compensation was $\$ 2.96$.

For English names, the average compensation was $\$ 68.08$. This was one of the lowest averages amongst the sections of names. They had the highest amount of compensation, however, at $\$ 2,907.20$. Their lowest amount of compensation was $\$ 0.45$.

The names which were classified as "excluding Irish" had an average rate of compensation of \$71.84. They had the same highest and lowest amount of compensation as did the English names. Those rates were $\$ 2,907.20$ and $\$ 0.45$. 
DIMAND, HINES, GONG, O'REILLY, VELK, ZHAO $19^{\text {th }}$ Century Economic Activity

\section{7-1869}

There was a greater division amongst the names in the second part of the New Hampshire data than the first. For New Hampshire, the names were divided into Irish, Mayflower, English, Other, and Unknown. In total, the average amount of compensation was \$239.51. The highest amount of compensation was $\$ 3,800$, and the lowest was $\$ 0.2$.

For the Irish names, the average rate of compensation was $\$ 131.31$. The highest amount of compensation was $\$ 3,100$, and the lowest was $\$ 0.22$.

For the Mayflower names, the average amount of compensation was $\$ 101.88$. The highest amount of compensation was $\$ 1,700$. The lowest amount of compensation was $\$ 0.72$.

Those of English origin had a total amount of compensation of $\$ 125.14$. Their highest amount of compensation was $\$ 3,800$, and their lowest was $\$ 0.2$.

For the names that were classified as Other, their average amount of compensation was $\$ 120.75$. Their highest amount of compensation was $\$ 3,100$, and the lowest amount was $\$ 0.2$.

Finally, the names that were of an unidentified ethnic origin had the highest average of compensation. Their average was $\$ 159.32$. Their highest amount of compensation was $\$ 3,000$, and their lowest amount of compensation was $\$ 0.45$.

\section{Analysis:}

\section{Women:}

In the first section, none of the postmasters were women. In the second section however, there were some postmaster women. They were:

\begin{tabular}{|l|l|l|l|}
\hline Year & Name & Compensation & Town \\
\hline \hline 1847 & Carroll House & Lucy Crawford, to $30^{\text {th }}$ May & 0.34 \\
\hline 1853 & East Plainfield & Miss Susan Martin & 37.65 \\
\hline 1853 & Tuttle's Corner & Christiana R. Tuttle & 29.79 \\
\hline 1853 & Durham & Mrs. Mary A. Page, to May 31 & 8.11 \\
\hline 1855 & East Plainfield & Susan Ann Martin & 45.05 \\
\hline 1855 & Seabrook & Susan Ann Brown & 58.4 \\
\hline 1857 & Sea Brook & Susan Ann Brown & 68.85 \\
\hline 1859 & Seabrook & Susan Ann Brown & 82.13 \\
\hline 1861 & Seabrook & Sarah Ann Brown & 71.86 \\
\hline 1861 & Peterboroug & Susan M. Gates, from Mar. 1 & 93.79 \\
\hline 1863 & Seabrook & Sarah Ann Brown & 79.42 \\
\hline
\end{tabular}


Review of Economic Analysis 12 (2020) 1-57

\begin{tabular}{|l|l|l|l|}
\hline Year & Name & Compensation & Town \\
\hline \hline 1863 & Chichester & Mrs. Betsey Langley, 2 qrs. & 1302.67 \\
\hline 1863 & Newbury & Mary Lear, 2 qrs. & 452.09 \\
\hline 1865 & Seabrook & Sarah Ann Brown & 87.07 \\
\hline 1865 & Newbury & Mary Lear & 314.84 \\
\hline 1865 & Hillsborough Centre & Elizabeth Nelson & 638.23 \\
\hline 1867 & Madison & Miss A. B. Atkinson, from May 23 & 2029.86 \\
\hline 1867 & Newbury & Mary Lear & 820 \\
\hline 1867 & Hillsborough Centre & Mrs. E. Nelson. & 960 \\
\hline 1867 & Upper Glimantons & Miss A. F. Johnston & 35 \\
\hline 1867 & Auburn & Mary A. Willey & 7.55 \\
\hline 1869 & Newbury & Mary Dear & 30.77 \\
\hline
\end{tabular}

Clearly some of the women who were postmasters in New England experienced a significant amount of wealth from the position. Mrs. Betsey Langley, for example, earned a significant wage as a postmaster in Chichester after working there for only two quarters.

Chichester is an interesting town to study. In the 1700s it was a relatively small town that experienced a significant rate of growth once transportation routes were developed to access the town. The town became much more prosperous. Because of their booming enterprises in manufacturing and agriculture, Chichester was able to contribute greatly to the Civil War, both with goods and men. This could be why Mrs. Langley held the position of postmaster: was her husband away at war. This is the sort of question we will explore as this study evolves. It is also significant to note the date of her position. In Chichester, their Suncook Railroad (a great endeavor) was completed after the Civil War. Once it was completed, many people migrated out of Chichester to look for more opportunities in larger cities. The railroad helped these people migrate out of the town. Therefore, Chichester's economy worsened. Most likely, Mrs. Langley's wages would have decreased if she kept the position after the Civil War. ${ }^{68}$ In fact, if you look at the one of the postmasters of Chichester in 1869, named J.H. Leavitt, his or her wage was significantly decreased. Though for the year this person earned $\$ 1,800$ - more than Mrs. Langley - their annual income was less than what Mrs. Langley's annual income had been if she worked more than her two quarters. In two quarters, Mrs. Langley earned \$1302.67. If she had worked for an entire year, she might have earned \$2,605.34. Leavitt, in comparison, only earned $\$ 1,800$ for the entire year - \$800 less than Mrs. Langley's potential earnings.

A lot of these women earned considerably more than they would have had they worked in a nearby mill. Women working in a mill in New England in the mid-1800s earned an average

68 "History of Chichester," from Town of Chichester. 
DIMAND, HINES, GONG, O’REILLY, VELK, ZHAO $19^{\text {th }}$ Century Economic Activity

wage of $\$ 2.50$ a week. $^{69}$ This meant that in a year, they earned approximately $\$ 130.00$. Clearly, the postmaster position was a significant employment, especially for women.

\section{Massachusetts:}

\section{Observations:}

\section{Ethnicities:}

There was a remarkable variation in ethnicity, with most people of Scottish and German descent. The vast majority, however, was of English ethnicity.

\section{Compensation:}

The average compensation for all of the postmasters was approximately $\$ 335.74$. The maximum compensation was $\$ 6,722.80$ received by G.H. Pierson, and the minimum was $\$ 0.04$, received by Ebenezer Tucker.

For the Irish names (which included those with both Irish ethnicity and otherwise), the average compensation was $\$ 201.95$. The maximum amount of compensation was $\$ 3,768.77$ that was received by George W. Goodman. The minimum amount of compensation was $\$ 0.04$, again received by Ebenezer Tucker, making this the smallest amount of compensation given out. The Irish population made up around $18 \%$ of the total population for postmasters.

The Mayflower demographic of the postmaster compensation data for Massachusetts only comprised $4 \%$ of the entire population. Their average compensation was $\$ 145.86$, and achieved a maximum of $\$ 2,600$ and a minimum of $\$ 1.97$.

English ethnicity was by far the largest demographic. They were almost $90 \%$ of the population (88.8\%). Their average compensation was $\$ 185.92$. Their maximum compensation was also $\$ 6,722.80$ received by G.H. Pierson (the highest amount of compensation given to any postmaster) and their minimum compensation was also $\$ 0.04$, also received by Ebenezer Tucker.

There was a large percentage of the population that might have had an ethnicity other than Irish, English, or of Mayflower ancestry. Usually, they shared one of those ancestries, but for a lot of the people, their surnames revealed that they might have been from a number of different countries. Those categorized under "other" made up 39\% of the population. They had a maximum compensation of $\$ 193.98$. Their maximum compensation was also $\$ 6,722.80$, but their minimum amount of compensation was $\$ 0.32$.

${ }^{69}$ Edward Pessen "Builders of the Young Republic" from United States Department of Labour. 
Finally, a small number of people had surnames that were unidentifiable. They made up roughly $3 \%$ of the total population of postmasters. Their average amount of compensation was $\$ 187.85$. They had a maximum compensation of $\$ 2,600$, and a minimum amount of compensation of $\$ 0.42$.

\section{Analysis:}

\section{Women:}

One of the most interesting observations in the data is the occurrence of females as postmasters in Massachusetts. Supposedly, ever since the 1800 s women were given positions as postmasters as well, and were paid equally. That is, the postmaster pay formula was sex-blind. Some reports announce that in the $1800 \mathrm{~s}$, women occupied $10 \%$ of postmaster positions ${ }^{70}$. From our data, we can see that this is untrue. In Massachusetts, there were only about 30 women who occupied the position of postmaster, meaning that only $0.2 \%$ of the position was occupied by women.

It is also interesting to study how and why the women received these positions. Instead of them gaining the position because of their abilities, they most likely came from prominent families where the male figures' influence allowed them to have a job as a postmaster. The women might have also taken over the job for their husband. For example, in 1867 George Chipman occupied the position of postmaster until Dec. $31^{\text {st }}$, when Miss. H.K. Chipman took it over on January $1^{\text {st }}$. They were both paid the same amount, and they both came from Scotland, Massachusetts. George Chipman had had the position as early as 1816 . This demonstrates that Miss. H.K. Chipman might have been a relative of George Chipman, and might have received it if he had gone to fight in the war as a way to 'reserve' the position, or keep the political influence and status the position of postmaster had within the community where in the Chipman family had standing. In fact, oftentimes women only worked as postmasters so that they could be "substitutes for male family members" ${ }^{71}$ Therefore, one might be able to infer that the postmaster position was still fairly exclusive, even though they did hire women. It is important to mention how all of the surnames of the "Miss" women - except for Este - are of English origin. ${ }^{72}$ Most of the most powerful people in Massachusetts were of English origin. Therefore, their employment might only be an example of their families' power instead of the post office as an inclusive area or as a ladder to success. It may be that standing and influence was earned elsewhere, and the post office job was a mere sign of pre-existing status.

\footnotetext{
70 "Women in Postal History: Worse than Reconstruction?", Smithsonian National http://postalmuseum.si.edu/womenhistory/women_history/history_reconstruction.html

${ }^{71}$ Ibid.

${ }^{72}$ Some in addition to English origin are Irish, Scottish, French or German.
} 
DIMAND, HINES, GONG, O’REILLY, VELK, ZHAO $19^{\text {th }}$ Century Economic Activity

"Miss" Postmasters

\begin{tabular}{|l|l|l|l|}
\hline Year & Name & Compensation & Town \\
\hline \hline 1861 & Miss Abigail W. Gardiner & 503.22 & Hingham \\
\hline 1863 & Miss Lizzie Elwell, from Feb 20 $0^{\text {th }}$ & 29.22 & Riverdale \\
\hline 1867 & Miss Amelia Snow, to Oct. 31 ${ }^{\text {st }}$ & 113.64 & Orleans \\
\hline 1867 & Miss Lizzie Elwell & 17.05 & Riverdale \\
\hline 1867 & Miss H.K. Chipman from Jan $1^{\text {st }}$ & 18 & Scotland \\
\hline 1869 & Miss A.E. Newton & 12 & Fayville \\
\hline 1869 & Miss L. A. White, from May $8^{\text {th }}$ & 81.59 & Newton Center \\
\hline 1869 & Miss H.K. Chipman & 50 & Scotland \\
\hline 1869 & Miss S.W. Este & 380 & Southborough \\
\hline 1869 & Miss E.A. Soule & 23 & West Beckett \\
\hline 1869 & Miss F.S. Everett & 30 & West Foxborough \\
\hline 1869 & Miss A.R. White, to March 31 $1^{\text {st }}$ & 426.5 & Weymouth \\
\hline
\end{tabular}

From the "Mrs." Category, all names except McIntire, ${ }^{73}$ Van Deusen, ${ }^{74}$ and Helmstead ${ }^{75}$ are English. This again most likely demonstrates the woman's family influence, instead of equality within the postmaster position.

“Mrs." Postmasters:

\begin{tabular}{|l|l|l|l|}
\hline Year & Name & Compensation & Town \\
\hline 1853 & Mrs. Sarah A. Nowell & 624.08 & Chelsea \\
\hline 1861 & Mrs. Semantha Clark & 18.85 & Beckett \\
\hline 1861 & Mrs. Dorothy Wells & 35.11 & East Charlemont \\
\hline 1861 & Mrs. Eliza Longley & 30.18 & Hawley \\
\hline 1861 & Mrs. Hamlet Hodges & 312.89 & Norton \\
\hline 1863 & Mrs. Emily Allen, 3 qrs & 73.75 & Beverly Farms \\
\hline 1865 & Mrs. Sampson Allen & 49.42 & Chilmark \\
\hline 1867 & Mrs. H.B. Huckins & 260 & Brewster \\
\hline 1867 & Mrs. S. S. Day & 930 & Brighton \\
\hline 1867 & Mrs. J. A. McIntire & 83 & Charlton City \\
\hline 1867 & Mrs. A. L. Damon & 94 & East Marshfield \\
\hline 1867 & Mrs. M. A. Robinson & 720 & Jamaica Plains \\
\hline 1867 & Mrs. N. I. Vining & 48 & Leydon \\
\hline 1867 & Mrs. A. R. Ensign & 590 & Sheffield \\
\hline 1867 & Mrs. S. F. Bacon & 760 & Southbridge \\
\hline
\end{tabular}

\footnotetext{
${ }^{73}$ Scottish

${ }^{74}$ Dutch/German

75 unknown
} 
Review of Economic Analysis 12 (2020) 1-57

\begin{tabular}{|l|l|l|l|}
\hline 1867 & Mrs. Jane Van Deusen & 78 & Van Deusenville \\
\hline 1867 & Mrs. Mercy Rider & 73 & West Brewster \\
\hline 1867 & Mrs. H. E. Helmstead & 830 & Wilbraham \\
\hline 1869 & Mrs. M. B. Huckins & 300 & Brewster \\
\hline 1869 & Mrs. C. P. Kelley & 230 & Cotuitport \\
\hline 1869 & Mrs. S. S. Day & 1100 & Brighton \\
\hline 1869 & Mrs. U. B. Graves, from June 22 & 6.68 & Hatfield \\
\hline 1869 & Mrs. A. R. Ensign & 510 & Sheffield \\
\hline 1869 & Mrs. S. F. Bacon, to March 31 $1^{\text {st }}$ & 577.5 & Southbridge \\
\hline 1869 & Mrs. Trephena Turner, from Ap. $1^{\text {st }}$ & 12.75 & Southfield \\
\hline 1869 & Mrs. Mercy Rider & 55 & West Brewster \\
\hline 1869 & Mrs. H. E. Hemstead & 830 & Wilbraham \\
\hline
\end{tabular}

In fact, Mrs. Jane Van Deusen's family most likely had extreme influence, as it seems the town was named after her family. In the 1800s, Van Deusenville was an extremely prosperous town. In 1837, the town gained a bank in addition to having two factories, a tavern, and an Episcopal church. ${ }^{76}$ Mrs. Van Deusen was most likely a relative of Isaac L. Van Deusen, who helped build the town through numerous enterprises. He also worked as a representative of the town in the General Court, and was the town treasurer. It is possible that Mrs. Jane Van Deusen attained the position of postmaster because of her family's great economic and political influence on the town.

A large amount of female names were without title. Mrs. A. R. Ensign of Sheffield is most likely the same Abigail R. Ensign listed below. This could either mean that the transcriber of the names made a mistake when omitting her title, or that Abigail was elderly and unmarried.

Unknown Title Names:

\begin{tabular}{|c|c|c|c|}
\hline Year & Name & Compensation & Town \\
\hline 1851 & Mary Wells & 6.32 & Shelburne \\
\hline 1853 & Lilley Eaton, to June $2^{\text {nd }}$ & 358.58 & South Reading \\
\hline 1857 & Cynthia S. Norway, from Jan. $8^{\text {th }}$ & 2.79 & East Brewster \\
\hline 1859 & Eliza Langley, 2 qrs. & 9.87 & Hawley \\
\hline 1865 & Abigail R. Ensign & 120 & Sheffield \\
\hline 1865 & Elizabeth Sanders & 49 & Middlesex Village \\
\hline 1867 & Clara P. Holman, from Oct. $1^{\text {st }}$ & 40.5 & Douglas \\
\hline 1867 & Ann R. White, from Oct. $1^{\text {st }}$ & 487.5 & Weymouth \\
\hline 1869 & Hattie E. Farnsworth, from Ap. $1^{\text {st }}$ & 160 & Groton \\
\hline 1869 & Martha A. Langley, from May $13^{\text {th }}$ & 255.77 & East Cambridge \\
\hline 1869 & Rebecca Paine, to Sept. $30^{\text {th }}$ & 21 & Eastham \\
\hline
\end{tabular}

${ }^{76}$ Taylor (1928): 414 
DIMAND, HINES, GONG, O'REILLY, VELK, ZHAO $19^{\text {th }}$ Century Economic Activity

\section{Wages Compared to Living Costs:}

Some of these people earned an incredibly high wage from their position as postmaster. Others earned comparatively little. For example, the highest amount of compensation, which was $\$ 2,600$, would have easily supported a family in great style. The minimum amount of compensation (\$0.04) would have had practically no economic effect on the family. Daily household goods, such as coffee, soap, milk or tea, were worth between $\$ 0.35$ and $\$ 1.00$ individually. Rent could have been about $\$ 4.00$ a week, depending on the house and area. Some estimate that the necessary weekly amount of money a family needed to make was around $\$ 15$ $\$ 20 .^{77}$ Clearly, some of these amounts of compensation would not have been enough to sustain a family. In fact, if one rounded the weekly expenditures per family to $\$ 20$, you would need to make roughly $\$ 1,060$ in order to meet that weekly cost of living.

\section{Vermont:}

\section{Observations:}

From the Vermont Name database, the majority of the names were English Protestant. Oftentimes, one name might have been an identifier of all of the ethnicities. For example, the surname Moore was categorized as Irish, a name from the Mayflower immigrants, and as an English Protestant last name.

One of the most interesting findings was that many people's last names differed from Irish, Mayflower or English. When this occurred, the surnames were Dutch, German, Scottish or French.

For the compensation data, the average compensation for those with Irish surnames was approximately $\$ 58.35$. The maximum compensation was $\$ 806.13$, and the minimum compensation was $\$ 0.52$. For the Mayflower surnames, the average compensation was $\$ 118.06$. The maximum compensation was $\$ 1217.27$, and the minimum was $\$ 1.71$. For English surnames, the average compensation was $\$ 76.20$. The maximum was $\$ 1021.37$, and the minimum amount of compensation was $\$ 0.37$. For Dutch surnames, the average amount was $\$ 60.82$. The maximum compensation was $\$ 341.25$, and the minimum was $\$ 3.46$. Finally, for the names I classified as "other", the average compensation was $\$ 68.74$. The maximum was $\$ 410.36$, and the minimum was $\$ 1.52$.

There were also some names whose origin could not be determined. One can only speculate as to why these names could not be identified. One reason might be that the names were transcribed improperly. For example, one person whose ethnicity could not be identified was Walter. Throughout the data, this person's last name was spelt in a variety of different ways. It

${ }^{77}$ Milton Meltzer (1967). 
was either "Chaffe", "Chaffey" "Chaffy", or "Chaffer". This variety of spelling might mean that the person's last name was neither Irish or English, and the repeated variations of the name might have resulted from appropriating a uncommon non-English surname. One can infer that this is the same person, as the variations of that name all came from the same town.

From the data, $79 \%$ were of English origin. Approximately $8 \%$ might have been of an origin other than English and Irish ethnicity or of the Mayflower. Add percentages in the observations. Approximately 2\% might have been of Dutch origin. Around 4\% were of Mayflower ancestry, and finally $9 \%$ were of Irish origin. All were most likely white and male. These percentages include those who might have had a last name that was more than one ethnicity. Most of the people worked more than one year as a postmaster. Another interesting observation is that some people were postmasters in towns that had their same last name. One might be able to infer that the town was named after their families, since postmasters usually came from influence and whose families had pull and political power.

\section{Analysis:}

For some towns, there might have been two postmasters, but one would have been paid significantly more than the other one. For example, in 1845 in Saint Johnsbury, there were two people who occupied the position of postmaster. One was William Stoughton, and the other was Moses Kittredge. While Stoughton was paid \$72.06, Kittredge was paid \$301.25. There is no evidence in the data that explains one person worked for a shorter period than the other (as it does in other parts of the data). In the east part of St. Johnsbury, David Goodall made \$61.59.

The names were also Dutch, Scottish, French and German. This is interesting. English people were paid the most and towns might have been named after them. This is difficult to understand completely since it is hard to locate the percentage of the people of Vermont who were English, Scottish, of Mayflower ancestry or of another ethnicity. For example, it is most likely that the English were the largest ethnicity in England, so they are more likely to have the highest and lowest amount of compensation.

The position of postmaster was an extremely important position. Many prominent "giants" of the United States held positions as post masters, such as Benjamin Franklin and Abraham Lincoln. Therefore, the position offered a way of socio-economic ascension. That is why it is interesting to see how other ethnicities - such as Irish, Dutch, German and French - occupied this position. One might be able to infer that the post office was less discriminatory than other positions in America. ${ }^{78}$

78 The United States Postal Service, An American History 1775-2006
https://about.usps.com/publications/pub100.pdf.


DIMAND, HINES, GONG, O'REILLY, VELK, ZHAO $19^{\text {th }}$ Century Economic Activity

\section{The Ethnicities:}

\section{Irish:}

It is not surprising to see that people of Irish ethnicities were a prominent demographic in Vermont in the 1800s. By 1850, the Irish were half of the immigrant population coming to the United States. Though Irish immigrants were numerous in the mid- $19^{\text {th }} \mathrm{C}$., the data demonstrates how Irish immigrants were prominent members of society prior to the $1850 \mathrm{~s}$, as the data demonstrates how many Irish occupied postmaster positions in the 1810s.

Jewish:

From the data, there is also some indication that postmasters might have been of Jewish origin. For example, Jacob Sax, a postmaster from High Gate, Vermont might have been Jewish. Some imply that Jewish peoples (especially Russian Jewish people) did not come to Vermont until the 1870s. Jacob Sax, however, offers a different insight, since he occupied the postmaster position in 1816.

\section{French:}

French names as well present in the data might demonstrate French-Canadians immigrating to Vermont. Supposedly, in the 1820s French-Canadians immigrated to Vermont and were driven out of Quebec and Canada due to a poor economy. The postmasters A. Chamberlin and E. Chamberlin, John Ives, and Douglass Barnard who occupied the position between 1816 and 1845 (and Joseph Loup in 1823) might show how French-Canadian immigrants flourished in Vermont.

\section{Scottish:}

Though Scottish were similar to the French in that they held more prominent jobs than did the Irish, of the compensation data only 146 postmasters might have been of Scottish origin. This figure would be more significant if there was an overall percentage accessible of Scottish peoples in Vermont at this time, but it still demonstrates how more Irish people held post-master positions than did Scottish people. ${ }^{79}$

\section{Compensation Comparison:}

Overall, those of Mayflower origin had the highest average of compensation at \$118.06. The lowest average of the 5 groupings was Irish, with an average of approximately $\mathbf{\$ 5 8 . 3 5}$. The Mayflower surnames also had the highest maximum compensation, at \$1217.27. Those with Dutch-origin last names received the lowest maximum amount of compensation, at \$341.25. Finally, the surname with the highest minimum amount of compensation was Dutch at \$3.46.

\footnotetext{
${ }^{79}$ Guyette (1992).
} 
Review of Economic Analysis 12 (2020) 1-57

The surname that received the lowest minimum amount of compensation was English, with a compensation of only $\mathbf{\$ 0 . 3 7}$.

\section{Connecticut:}

\section{Observations:}

From the Connecticut Name database, the majority of names were English Protestant. In most cases, a name would have more than one identified ethnicity. For example, the surname Cook was categorized as Irish, a name from Mayflower immigrants, and English Protestant.

Many of the last names differed from Irish, Mayflower or English. The surnames were often Dutch, German, Scottish, French, Scandinavian and Jewish.

The compensation data indicates that those with Irish surnames received an average compensation of $\$ 165.87$. The maximum compensation was $\$ 2,800$, while the minimum was $\$ 0.28$. For those with English surnames, the average compensation was $\$ 152.03$. The minimum compensation was $\$ 0.1$, while the maximum was $\$ 4,000$. For those with surnames that were present on the Mayflower, the average compensation was \$183.64. The maximum compensation was $\$ 2,500$ while the minimum was $\$ 1.43$.

For names which included German ethnicity, the average compensation was $\$ 144.61$. The minimum compensation was $\$ 0.28$ while the maximum was $\$ 2,327.29$. For names which included Dutch ethnicity, the average compensation was $\$ 158.94$. The minimum compensation was $\$ 1.77$, while the maximum compensation was $\$ 3,273.81$. Those with a Scottish surname received an average compensation of $\$ 170.64$. The maximum compensation was $\$ 3302.15$, while the minimum $\$ 0.28$. For those with a Jewish surname, the average compensation was $\$ 197.65$. The maximum compensation was $\$ 1222.7$, while the minimum was $\$ 0.28$. For those with French surnames, the average compensation was $\$ 111.69$. The maximum compensation was $\$ 1209.3$, while the minimum compensation was $\$ 4.78$. Finally, for those names which were neither English, Mayflower or Irish, the average compensation was $\$ 105.53$. The maximum compensation was $\$ 1025.9$, while the minimum compensation was $\$ 0.77$.

There are some names which could not be determined and are marked as "Unknown" in the data set. In many cases the name was improperly transcribed from the data. Some names which were Americanized could not be rooted to their original ethnicity due to the change in spelling.

From the data, $90.3 \%$ of names were of English origin, but categorized with other ethnicities as well. The names which were solely of English descent constituted $52.5 \%$ of the names collected. Names with Irish origin totalled $15.7 \%$ of names, and the names that were solely Irish were $5.2 \%$ of the total names. The names which came from Mayflower ancestry constituted $3.5 \%$ of total Vermont names.

Dutch names accounted for $2.6 \%$ of total names. German names made up $14.9 \%$ of the total names. Scottish names made up $13.9 \%$ of the total names, while Jewish names made up $1.6 \%$ 
DIMAND, HINES, GONG, O'REILLY, VELK, ZHAO $19^{\text {th }}$ Century Economic Activity

of the total names. Finally, French names made up $1.1 \%$ of the names, and Scandinavian account for $0.4 \%$ of the total. These percentages include those who have a last name that was more than one ethnicity. Most people worked more than one year as postmaster.

\section{Analysis:}

In many towns, one postmaster was paid much higher than the other. There is no evidence to explain why this is the case. For example, in Killingly, Samuel Beecher was paid \$33.09 in 1853, while Benjamin Thomas received $\$ 435.78$.

Further, one single postmaster may have a large income disparity between given years. For example, Oliver Green in East Haddam was compensated \$1,222.70 in 1835, but only \$205.24 in 1839 .

While most of the names listed were of English origin, the difference between the average income of English postmasters and those of other ethnicities is not large. Those with last names of the Mayflower type received the highest average income at $\$ 183.64$. This could indicate that those from Mayflower ancestry would have had a stronger and more established position within the community, likely yielding more political pomp which could translate to a higher annual wage. Those with English last names received the second highest average income at \$165.87. Those with either Irish or Mayflower ancestry received a higher average income than those of English ancestry. This could be due, in part, to the fact that English names constituted 90.3\% of the total names, and thus would have included a wider span of those with or without political power in a given town. From our sample of postmaster generals, it would be safe to conclude that a majority of people within Connecticut were of English ancestry, who would have spanned many, if not all, of the economic classes.

From the data, it is possible to conclude that the position of postmaster general was not discriminatory towards those of different European ancestries. Those of Jewish ancestry faired particularly well, making, on average $\$ 197.65$ annually, higher than those with English, Irish or Mayflower surnames, while constituting only $1.6 \%$ of total postmaster generals.

While Irish names made up $15.7 \%$ of the total names in the dataset, Irish immigration to the state of Connecticut would indicate that the Irish made up a large percentage of the total populace. In the 1820's and 30's, the Irish made up more than one-third of the immigrants arriving in the country, and in the 1840 's they constituted nearly half. Later in the century, Irishborn citizens made up as much as $20 \%$ of the population in several major cities, including Hartford. Our data further supports that the prospering economies in Connecticut provided the main draw for early immigrants, with the state accommodating a steadily increasingly flow of English, Scottish, Irish, German, and Scandinavian arrivals. ${ }^{80}$

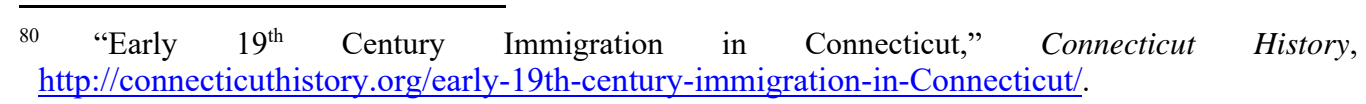


The average compensation for postmaster general would support the evidence that those towns with larger economies allowed postmasters higher incomes. For example, New Haven and Hartford have amongst them the highest average salary for postmaster generals. Hartford's average salary is the highest at $\$ 1,864.10$, while New Haven's amounted to $\$ 1,690.67$. This is because postmaster pay is linked to mail volume, and mail volume increases with population as well as with general economic (per capita) activity.

\section{Conclusion}

In this paper, we continued to demonstrate the potential application of our postal data. In this study, we combined information about the railroads with the postmaster compensation to study at a microeconomic level the impact of railroads on local economic activity, disaggregated to the level of individual post offices. From our point of view, we have once again supported an existing hypothesis that railroads made a difference. But, compared to existing estimates of US economic activity in the 19th century, our data has a great many more pixels than any previous work, and is based solidly on the actual dollar volume of each post office in the United States in each two-year period.

To summarize: railroad towns were more volatile, were more connected to the national business cycle, and were more rapidly growing than non-railroad towns. We were also able to differentiate growth rates and economic activity levels among and between the six New England states. To reiterate the micro dimension of our data, we were able to make state-bystate comparisons as to levels of economic activity, volatility and sensitivity to business cycles.

In our study of postmaster ethnicities, as revealed by postmaster names, we showed differences among the four states: New Hampshire, Vermont, Connecticut, and Massachusetts. In Massachusetts, arguably the most industrialized of these states, European names were common. In the states that we studied, names of other origins such as German, French, Scandinavian, and Jewish were present. While Mayflower names predominated in all the states and had the highest average compensation, it is interesting to discover that newer arrivals had enough political presence in New England to earn for them one of these coveted jobs.

Most interesting of all, there was a presence of women in these jobs that required political pull to get. It does seem that some of the women got the postmaster job because a male in the family had it before they did. Nonetheless, the women postmasters did exist and earned salaries well above working at the mills of New England. It should also be noted some of these women postmasters got the job independent of male family connections.

In our future studies, we may be able to conclude that railroad towns are more ethnically diverse and were possibly more important in terms of the spoils systems that awarded economically attractive postmasters jobs. In the work that remains to be done, we will look at the routes effect. We will examine more railroad towns and advance the demographic study where we compare railroad and non-railroad towns for ethnicity factors. Our next big venture 
DIMAND, HINES, GONG, O'REILLY, VELK, ZHAO $19^{\text {th }}$ Century Economic Activity

will be to use postmaster compensation to examine the Westward movement. Were frontier towns richer or poorer? Were they more ethnically diverse or rapidly growing than towns back East? These questions will be our next challenge.

\section{References}

Bélanger, C. (1999). French Canadian emigration to the United States 1840-1930. http://faculty.marianapolis.edu/c.belanger/quebechistory/readings/leaving.htm.

Bordo, M. (2003). Stock market crashes, Productivity booms, busts and recessions: Some historical evidence. CFR.org.

Brooke, J. (1993) Review of Joyce Botelho, Right and Might: The Dorr Rebellion and the Struggle for Equal Rights. Journal of American History 80, 192-198.

Davis, J. (2006). An improved annual chronology of US business cycles since the 1790s. Journal of Economic History 66, 103-121.

Demar, E. and Normen, E. (2011). Misread signal leads to deadly South Norwalk crash - Who knew? Connecticut Explored vol. 9(4), 14-19.

Guyette, E. (1992). Gathering and interactions of peoples, cultures and ideas. In Immigration to Vermont: 1840 to 1930 , http://www.flowofhistory.org/themes/movement_settlement/immigration.php.

Hines, T. and Velk, T. (2010). Explorations in the Official Register: Statistical analysis of postmaster compensation data from 19th Century New Hampshire. The Winton M. Blount Postal History Symposia, 2006-2009, Washington, DC: Smithsonian Institution Scholarly Press, 29-36.

Huston, J. (1983). Western grains and the panic of 1857. Agricultural History 57, 14-32

Linsell, R. and Kerr, R. (2000). The Rail Lines of Northern New England. Pepperell, MA: Branch Line Press.

Kerr, R. (2014). The Rail Lines of Southern New England. Pepperell, MA: Branch Line Press.

Meltzer, M. (1967). Bread and Roses: The Struggle of American Labor 1865-1915. New York: Knopf.

Miller, R. (2013). States at War, Volume 1: A Reference Guide for Connecticut, Maine, Massachusetts, New Hampshire, Rhode Island and Vermont in the Civil War. Lebanon, NH: New England Universities Press.

Nelson, D. (2011) Connecticut arms the nation. Connecticut Explored 9(2), 30-37.

Parillo, N. (2013). Against the Profit Motive: The Salary Revolution in American Government, 1780-1940. New Haven, CT: Yale University Press.

Rolnick, A., Smith, B. and Weber, W. (2000). The Suffolk Bank and the panic of 1837. Federal Reserve Bank of Minneapolis Quarterly Review 24(2), 3-13. 
Simon, M. (1963). The role of railroads in United States economic growth: Discussion. Journal of Economic History 23, 522-524.

Soltow, L. (1975). Men and Wealth in the United States, 1850-1870. New Haven, CT: Yale University Press.

Taylor, C. (1928). History of Great Barrington (Berkshire County), Massachusetts, 1676-1882, annotated by R. Pope and G. MacLean. Great Barrington, MA: Town of Great Barrington.

Temin, P. (1969). The Jacksonian Economy. New York: W. W. Norton.

Thies, C. (2002). The American railroad network during the early 20th century: Private versus public Enterprise. Cato Journal 22, 229-261.

Thorp, W. (1926). Business Annals. National Bureau of Economic Research. http://www.nber.org/chapters/c4638.pdf.

Zarnowitz, V. (1992) "Business Cycles and Growth," from V. Zarnowitz, Business Cycles: Theory, History, Indicators and Forecasting, National Bureau of Economic Research, http://www.nber.org/chapters/c10378.pdf.

\section{Appendix}

POSTMASTER COMPENSATION RATES:

1815 (Act of Feb. 27).

\begin{tabular}{|lc|lc|}
\hline Range & Percentage rate & Range & Percentage rate \\
\hline$\$ 0$ to $\$ 150$ & $20 \%$ & $\$ 0$ to $\$ 450$ & $17 \%$ \\
\hline$\$ 0$ to $\$ 3000$ & $13 \%$ & Over $\$ 3600$ & $5 \%$ \\
\hline
\end{tabular}

1816 (Act of April 9).

\begin{tabular}{|lllll|}
\hline Range & Size of range & Percentage rate & Increment & Total \\
\hline$\$ 0$ to $\$ 100$ & $(\$ 100)$ & $30 \%$ & $\$ 30.00$ & $\$ 30.00$ \\
\hline$\$ 101$ to $\$ 400$ & $(\$ 299)$ & $25 \%$ & $\$ 74.75$ & $\$ 104.75$ \\
\hline$\$ 401$ to $\$ 2400$ & $(\$ 1999)$ & $20 \%$ & $\$ 399.80$ & $\$ 504.55$ \\
\hline$\$ 2401+$ & \multicolumn{5}{|c}{$8 \%$} \\
\hline
\end{tabular}


DIMAND, HINES, GONG, O'REILLY, VELK, ZHAO $19^{\text {th }}$ Century Economic Activity

1847 (Act of March 1).

\begin{tabular}{|lllll|}
\hline Range & Size of range & Percentage rate & Increment & Total \\
\hline$\$ 0$ to $\$ 100$ & $(\$ 100)$ & $40 \%$ & $\$ 40.00$ & $\$ 40.00$ \\
\hline$\$ 101$ to $\$ 400$ & $(\$ 299)$ & $33.3 \%$ & $\$ 99.57$ & $\$ 139.57$ \\
\hline$\$ 401$ to $\$ 2400$ & $(\$ 1999)$ & $30 \%$ & $\$ 599.70$ & $\$ 739.27$ \\
\hline$\$ 2401+$ & $12.5 \%$ & & \\
\hline
\end{tabular}

1853 (Act of March 3).

\begin{tabular}{|lclll|}
\hline Range & Size of range & Percentage rate & Increment & Total \\
\hline$\$ 0$ to $\$ 100$ & $(\$ 100)$ & $50 \% *$ & $\$ 50.00$ & $\$ 50.00$ \\
\hline$\$ 101$ to $\$ 400$ & $(\$ 299)$ & $40 \%$ & $\$ 119.60$ & $\$ 160.60$ \\
\hline$\$ 401$ to $\$ 2400$ & $(\$ 1999)$ & $35 \%$ & $\$ 699.65$ & $\$ 860.25$ \\
\hline \$2401+ & & $15 \%$ & & \\
\hline$* 60 \%$ if between $9 \mathrm{pm} \& 5 \mathrm{am}$ \\
\hline
\end{tabular}

1854 (Act of June 22).

\begin{tabular}{|lllll|}
\hline Range & Size of range & Percentage rate & Increment & Total \\
\hline$\$ 0$ to $\$ 100$ & $(\$ 100)$ & $60 \% *$ & $\$ 60.00$ & $\$ 60.00$ \\
\hline$\$ 101$ to $\$ 400$ & $(\$ 299)$ & $50 \%$ & $\$ 149.50$ & $\$ 209.50$ \\
\hline$\$ 401$ to $\$ 2400$ & $(\$ 1999)$ & $40 \%$ & $\$ 799.60$ & $\$ 1009.10$ \\
\hline$\$ 2401+$ & $15 \%$ & & \\
\hline *70\% if between 9pm \& 5am & & & \\
\hline
\end{tabular}


1864 (Act of July 1).

Classes of post offices introduced based on compensation.

\begin{tabular}{|l|}
\hline $1^{\text {st }}$ class: $\$ 3000$ to $\$ 4000$ per year. \\
\hline $2^{\text {nd }}$ class $\$ 2000$ to $\$ 2999$ \\
\hline $3^{\text {rd }}$ class $\$ 1000$ to $\$ 1999$ \\
\hline $4^{\text {th }}$ class $\$ 100$ to $\$ 999$ \\
\hline $5^{\text {th }}$ class $\$ 0$ to $\$ 99$ \\
\hline
\end{tabular}

See 1921 report for details.

1872 (Act of June 6).

All box rents plus:

\begin{tabular}{|lllll|}
\hline$\$ 0$ to $\$ 100$ & $(\$ 100)$ & $60 \%$ & $\$ 60.00$ & $\$ 60.00$ \\
\hline$\$ 101$ to $\$ 400$ & $(\$ 299)$ & $50 \%$ & $\$ 149.50$ & $\$ 209.50$ \\
\hline$\$ 401$ to $\$ 2400$ & $(\$ 1999)$ & $40 \%$ & $\$ 799.60$ & $\$ 1009.10$ \\
\hline$\$ 2401+$ & \multicolumn{5}{|c}{$15 \%$} & \\
\hline
\end{tabular}

1874 (Act of June 23)

All box rents ( $\$ 2000$ max) plus:

\begin{tabular}{|lllll|}
\hline$\$ 0$ to $\$ 100$ & $(\$ 100)$ & $50 \%$ & $\$ 50.00$ & $\$ 50.00$ \\
\hline$\$ 101$ to $\$ 400$ & $(\$ 299)$ & $40 \%$ & $\$ 119.60$ & $\$ 169.60$ \\
\hline$\$ 401$ to $\$ 2400$ & $(\$ 1999)$ & $30 \%$ & $\$ 599.70$ & $\$ 769.30$ \\
\hline$\$ 2401+$ & & $10 \%$ & & \\
\hline
\end{tabular}


DIMAND, HINES, GONG, O'REILLY, VELK, ZHAO $19^{\text {th }}$ Century Economic Activity

1876 (Act of July 12).

See report for box rent details.

$1^{\text {st }}$ through $3^{\text {rd }}$ class offices:

\begin{tabular}{|lcccc|}
\hline$\$ 0$ to $\$ 100$ & $(\$ 100)$ & $60 \%$ & $\$ 60.00$ & $\$ 60.00$ \\
\hline$\$ 101$ to $\$ 300$ & $(\$ 199)$ & $50 \%$ & $\$ 99.50$ & $\$ 159.50$ \\
\hline$\$ 301$ to $\$ 700$ & $(\$ 399)$ & $40 \%$ & $\$ 159.60$ & $\$ 319.10$ \\
\hline$\$ 701+$ & $30 \%$ & & \\
\hline
\end{tabular}

$4^{\text {th }}$ class offices:

\begin{tabular}{|lllll|}
\hline$\$ 0$ to $\$ 100$ & $(\$ 100)$ & $60 \%$ & $\$ 60.00$ & $\$ 60.00$ \\
\hline$\$ 101$ to 300 & $(\$ 199)$ & $50 \%$ & $\$ 99.50$ & $\$ 159.50$ \\
\hline$\$ 301+$ & & $40 \%$ & & \\
\hline
\end{tabular}

1883 (Act of March 3)

For $1^{\text {st }}$ and $2^{\text {nd }}$ class offices, see p. 113 of 1921 report.

$3^{\text {rd }}$ class:

$\begin{array}{ll}\text { Receipts } & \text { Salary } \\ \$ 1900 \text { to } \$ 2100 & \$ 1000 \\ \$ 2101 \text { to } \$ 2400 & \$ 1100 \\ \$ 2401 \text { to } \$ 2700 & \$ 1200 \\ \$ 2701 \text { to } \$ 3000 & \$ 1300 \\ \$ 3001 \text { to } \$ 3500 & \$ 1400 \\ \$ 3501 \text { to } \$ 4200 & \$ 1500 \\ \$ 4201 \text { to } \$ 5000 & \$ 1600 \\ \$ 5001 \text { to } \$ 6000 & \$ 1700 \\ \$ 6001 \text { to } \$ 7000 & \$ 1800\end{array}$




\begin{tabular}{|lllll|}
\hline$\$ 0$ to $\$ 50$ & $(\$ 50)$ & $100 \%$ & $\$ 50.00$ & $\$ 50.00$ \\
\hline$\$ 51$ to $\$ 150$ & $(\$ 99)$ & $60 \%$ & $\$ 59.40$ & $\$ 109.40$ \\
\hline$\$ 151$ to $\$ 350$ & $(\$ 199)$ & $50 \%$ & $\$ 99.50$ & $\$ 208.90$ \\
\hline$\$ 351+$ & $40 \%$ \\
\hline
\end{tabular}

Table 1

\begin{tabular}{|r||r|r|r|r|r|l|}
\hline Year & $\begin{array}{l}\text { Rhode } \\
\text { Island }\end{array}$ & Connecticut & Maschusetts & Vermont & $\begin{array}{l}\text { New } \\
\text { Hampshire }\end{array}$ & Maine \\
\hline \hline 1835 & $\$ 2,000.00$ & & $\$ 533.63$ & & & $\$ 378.39$ \\
\hline 1837 & $\$ 746.04$ & $\$ 376.30$ & $\$ 561.12$ & & & $\$ 351.97$ \\
\hline 1839 & $\$ 758.44$ & $\$ 410.08$ & $\$ 704.44$ & & $\$ 241.01$ & $\$ 340.35$ \\
\hline 1841 & $\$ 739.81$ & $\$ 521.00$ & $\$ 678.70$ & & $\$ 246.90$ & $\$ 347.58$ \\
\hline 1843 & $\$ 672.31$ & $\$ 365.08$ & $\$ 555.57$ & $\$ 122.50$ & $\$ 195.52$ & $\$ 284.95$ \\
\hline 1845 & $\$ 436.68$ & $\$ 560.17$ & $\$ 500.94$ & $\$ 123.17$ & $\$ 170.77$ & $\$ 294.79$ \\
\hline 1847 & $\$ 583.24$ & $\$ 521.29$ & $\$ 543.17$ & $\$ 145.44$ & $\$ 212.91$ & $\$ 410.92$ \\
\hline 1849 & $\$ 438.28$ & $\$ 632.24$ & $\$ 608.01$ & $\$ 134.41$ & $\$ 250.88$ & $\$ 320.82$ \\
\hline 1851 & $\$ 397.13$ & $\$ 854.48$ & $\$ 705.97$ & $\$ 204.18$ & $\$ 357.15$ & $\$ 459.83$ \\
\hline 1853 & $\$ 355.63$ & $\$ 574.78$ & $\$ 511.30$ & $\$ 167.49$ & $\$ 202.80$ & $\$ 257.07$ \\
\hline 1855 & $\$ 451.38$ & $\$ 989.07$ & $\$ 784.79$ & $\$ 236.85$ & $\$ 377.48$ & $\$ 492.06$ \\
\hline 1857 & $\$ 452.21$ & $\$ 916.74$ & $\$ 802.99$ & $\$ 228.23$ & $\$ 362.90$ & $\$ 403.58$ \\
\hline 1859 & $\$ 491.12$ & $\$ 980.42$ & $\$ 777.03$ & $\$ 327.85$ & $\$ 400.25$ & $\$ 600.00$ \\
\hline 1861 & $\$ 441.06$ & $\$ 884.06$ & $\$ 766.70$ & $\$ 236.70$ & $\$ 298.16$ & $\$ 419.61$ \\
\hline 1863 & $\$ 715.60$ & $\$ 1,145.21$ & $\$ 1,038.59$ & $\$ 362.50$ & $\$ 500.88$ & $\$ 684.85$ \\
\hline 1865 & $\$ 1,100.31$ & $\$ 1,596.86$ & $\$ 1,206.42$ & $\$ 416.86$ & $\$ 538.23$ & $\$ 898.11$ \\
\hline 1867 & $\$ 1,204.77$ & $\$ 1,457.12$ & $\$ 1,194.06$ & $\$ 413.90$ & $\$ 557.16$ & $\$ 610.18$ \\
\hline 1869 & $\$ 1,337.92$ & $\$ 842.37$ & $\$ 1,521.66$ & $\$ 428.73$ & $\$ 436.86$ & $\$ 883.86$ \\
\hline
\end{tabular}


DIMAND, HINES, GONG, O'REILLY, VELK, ZHAO $19^{\text {th }}$ Century Economic Activity

Fig. 2: For Rhode Island Analysis

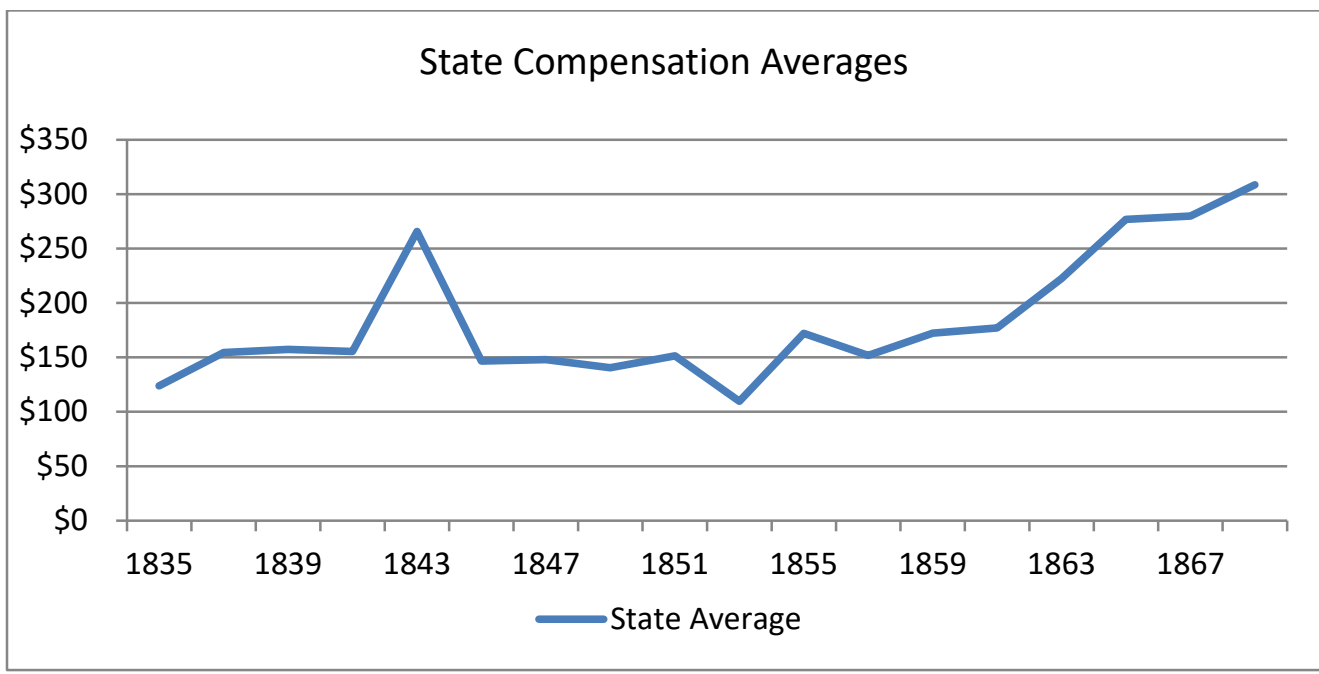

Fig. 3:

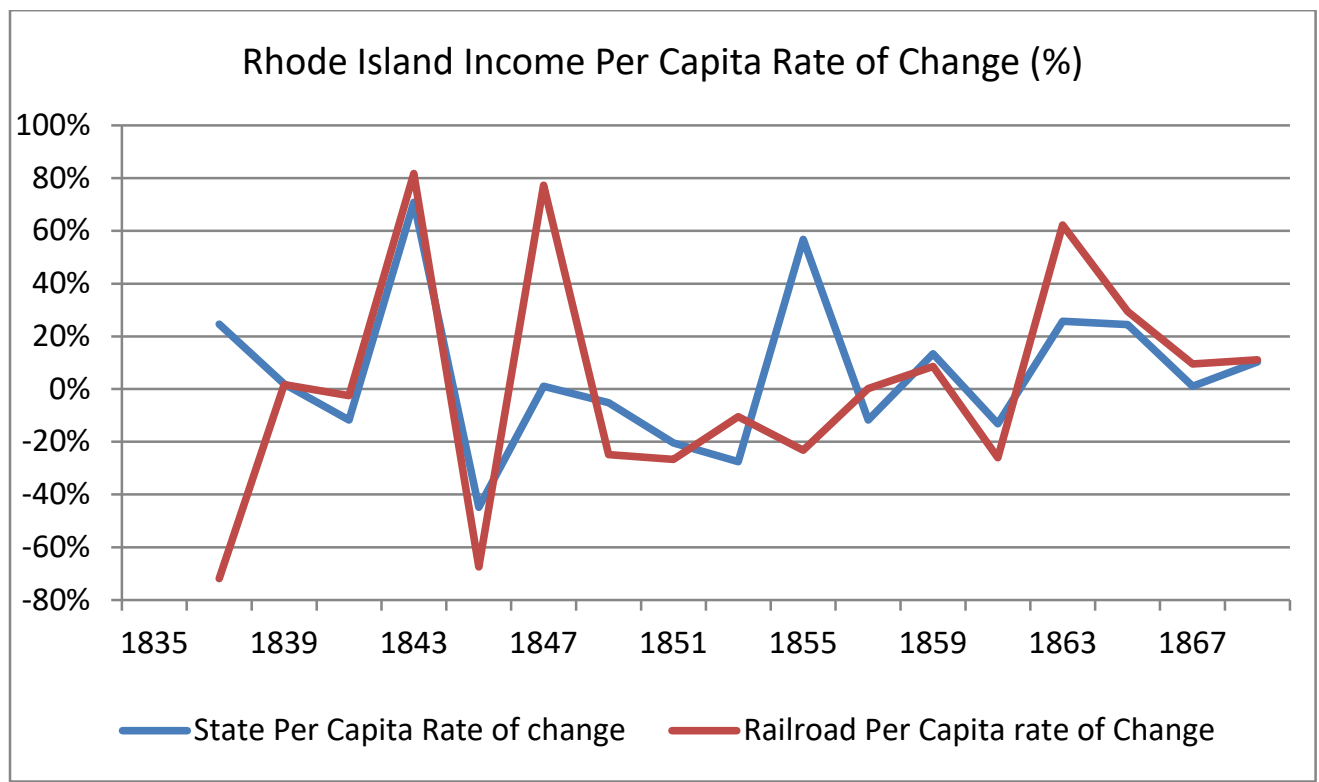


Review of Economic Analysis 12 (2020) 1-57

Chart 1: For Massachusetts Analysis

TABLE 1 TURNING POINTS IN THE PREWAR U.S. INDUSTRIAL ECONOMY, 1790-1915

\begin{tabular}{|c|c|c|c|c|}
\hline \multicolumn{2}{|c|}{ NBER Chronology } & \multicolumn{2}{|c|}{ Alternative Chronology } & \multirow{2}{*}{$\begin{array}{l}\text { Net Change to NBER } \\
\text { Phase Duration } \\
\text { (in years) }\end{array}$} \\
\hline Peak & Trough & Peak & Trough & \\
\hline \multicolumn{5}{|c|}{ Antebellum Industrial Cycles } \\
\hline 1796 & 1799 & 1796 & 1798 & less 1 \\
\hline 1802 & 1804 & 1802 & 1803 & less 1 \\
\hline 1807 & 1810 & 1827 & 1808 & less 2 \\
\hline 1811 & 1812 & 1811 & 1812 & \\
\hline 1815 & 1821 & 1815 & 1816 & less 5 \\
\hline 1822 & 1823 & 1822 & 1823 & \\
\hline 1825 & 1826 & & & no recession \\
\hline 1828 & 1829 & 1828 & 1829 & \\
\hline 1833 & 1834 & 1833 & 1834 & \\
\hline 1836 & 1838 & 1836 & 1837 & less 1 \\
\hline 1839 & 1843 & 1839 & 1840 & less 3 \\
\hline 1845 & 1846 & & & no recession \\
\hline 1847 & 1848 & & & no recession \\
\hline 1853 & 1855 & & & no recession \\
\hline 1856 & 1858 & 1856 & 1858 & \\
\hline \multicolumn{5}{|c|}{ Civil War Industrial Cycles } \\
\hline 1860 & 1861 & 1860 & 1861 & \\
\hline 1864 & 1867 & 1864 & 1865 & less 2 \\
\hline \multicolumn{5}{|c|}{ Postbellum Industrial Cycles } \\
\hline 1869 & 1870 & & & no recession \\
\hline 1873 & 1878 & 1873 & 1875 & less 3 \\
\hline 1882 & 1885 & 1883 & 1885 & less 1 \\
\hline 1887 & 1888 & & & no recession \\
\hline 1890 & 1891 & & & no recession \\
\hline 1892 & 1894 & 1892 & 1894 & \\
\hline 1895 & 1896 & 1895 & 1896 & \\
\hline 1899 & 1900 & & & no recession \\
\hline 1903 & 1904 & 1903 & 1904 & \\
\hline 1907 & 1908 & 1907 & 1908 & \\
\hline 1910 & 1911 & 1910 & 1911 & \\
\hline 1913 & 1914 & 1913 & 1914 & \\
\hline
\end{tabular}

Source: NBER 
DIMAND, HINES, GONG, O'REILLY, VELK, ZHAO $19^{\text {th }}$ Century Economic Activity

Fig. 4:

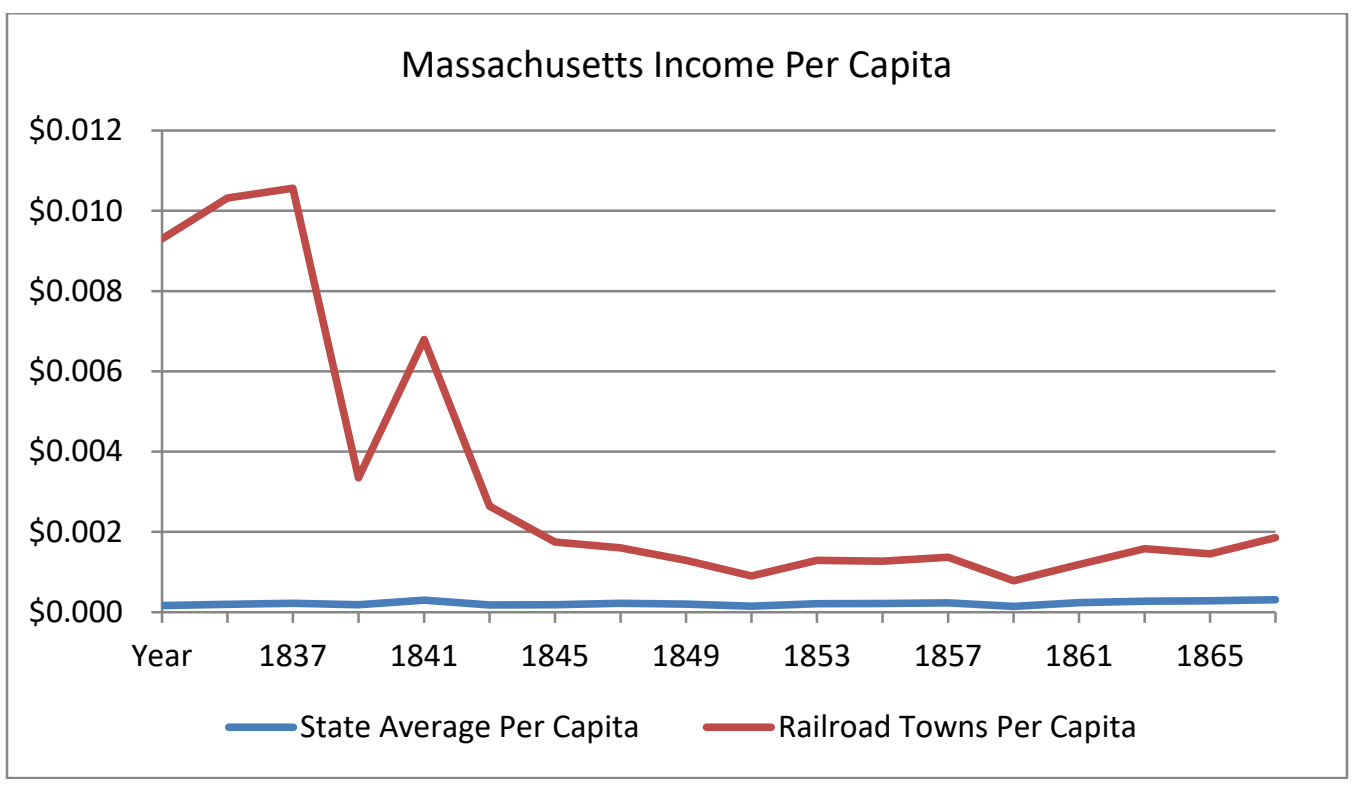

Fig. 5:

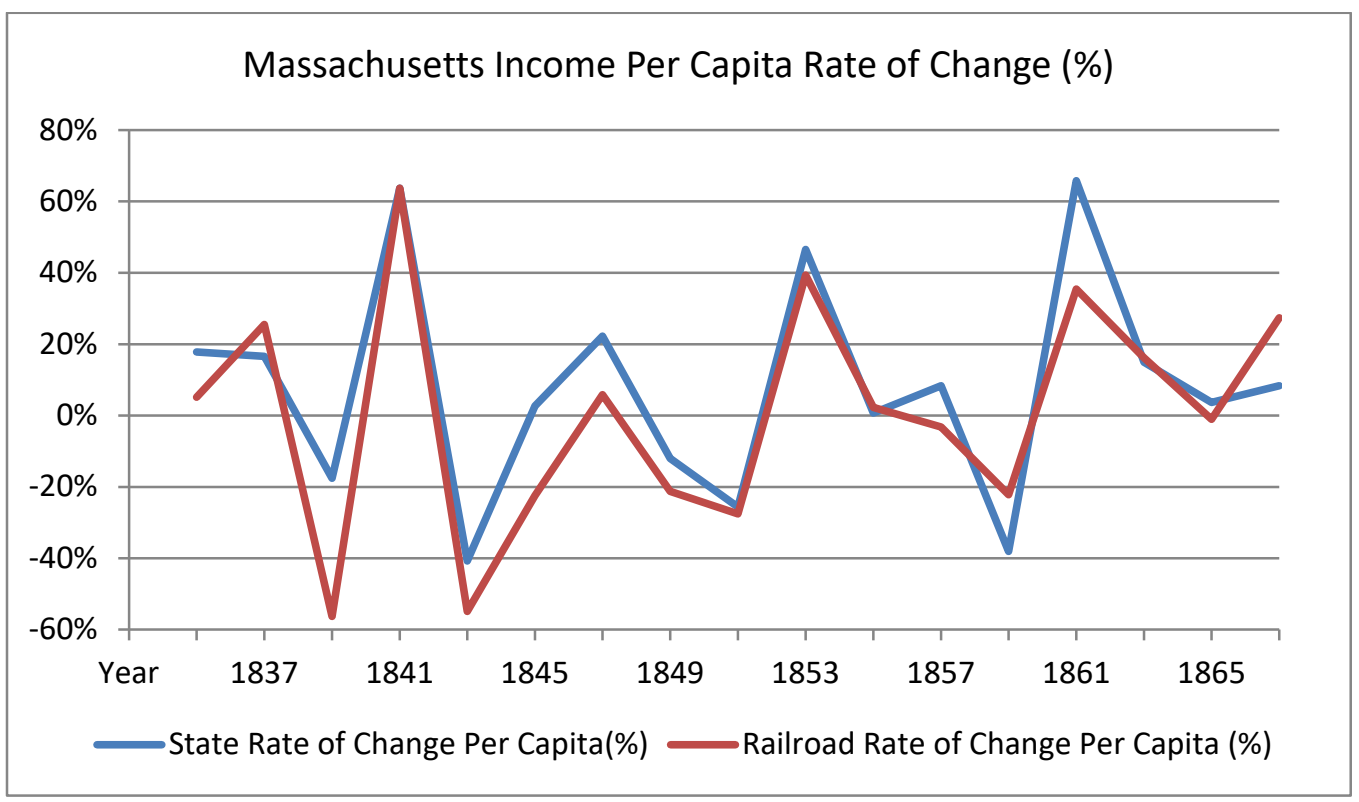


Review of Economic Analysis 12 (2020) 1-57

Fig. 6:

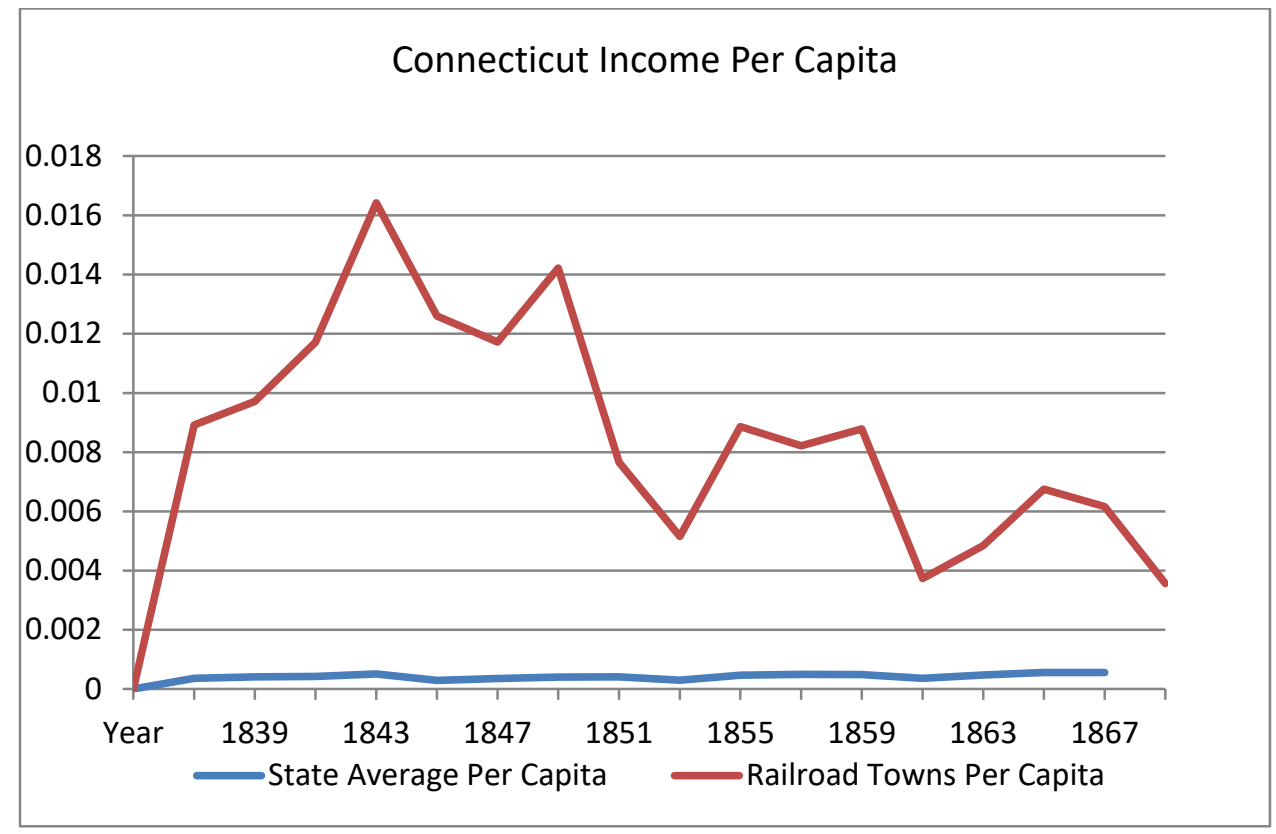

Fig. 7:

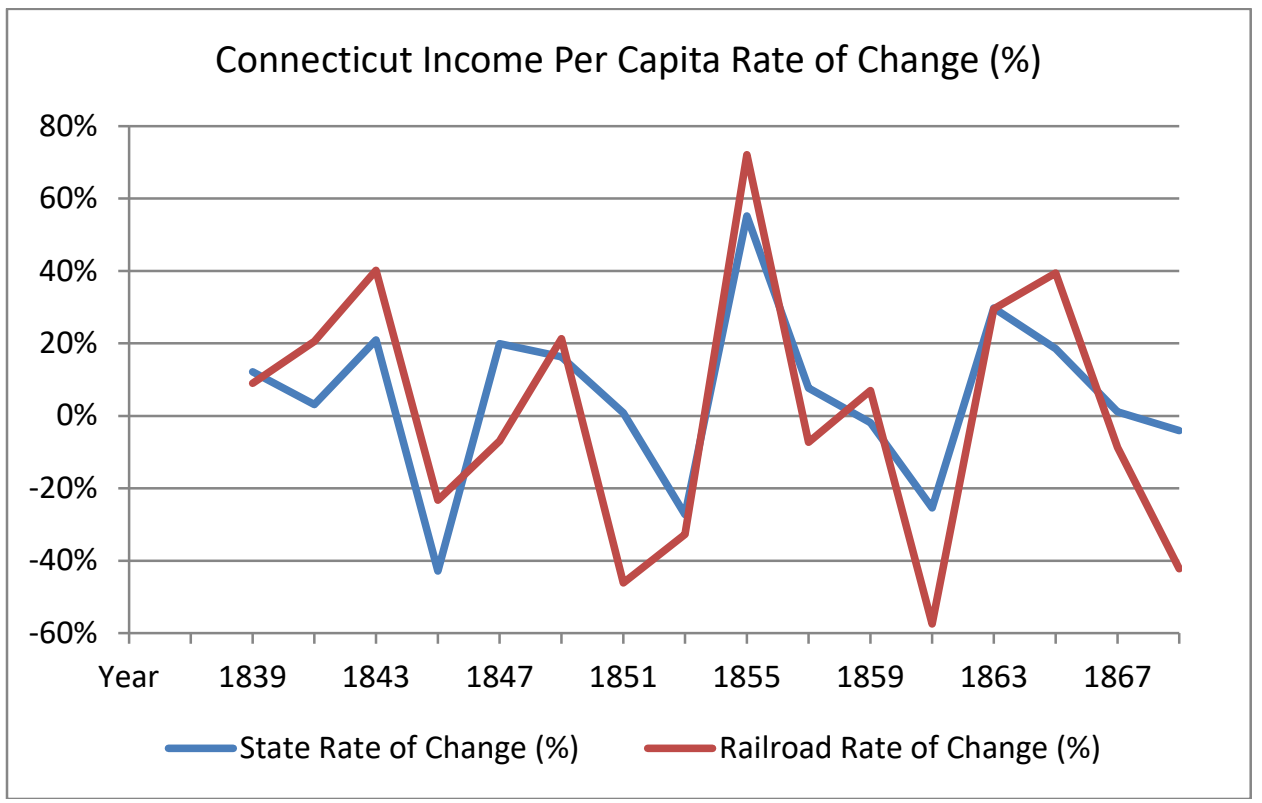


DIMAND, HINES, GONG, O'REILLY, VELK, ZHAO $19^{\text {th }}$ Century Economic Activity

For Connecticut Analysis

\begin{tabular}{|r|r|r|r|r|r|}
\hline Year & $\begin{array}{l}\text { State Average } \\
\text { Compensations }\end{array}$ & \multicolumn{2}{|l|}{$\begin{array}{l}\text { Railroad Town Average } \\
\text { Compensation }\end{array}$} & $\begin{array}{l}\text { State Rate of } \\
\text { Change (\%) }\end{array}$ & $\begin{array}{l}\text { Railroad Rate of } \\
\text { Change }\end{array}$ \\
\hline 1837 & $\$ 108.04$ & $\begin{array}{l}\text { Railroad } \\
\text { Towns }\end{array}$ \\
\hline 1839 & $\$ 121.15$ & $\$ 376.30$ & & & 3 \\
\hline 1841 & $\$ 130.11$ & $\$ 410.08$ & $12.13 \%$ & $8.98 \%$ & 3 \\
\hline 1843 & $\$ 157.37$ & $\$ 521.00$ & $7.40 \%$ & $27.05 \%$ & 5 \\
\hline 1845 & $\$ 89.90$ & $\$ 730.16$ & $20.95 \%$ & $40.14 \%$ & 5 \\
\hline 1847 & $\$ 107.78$ & $\$ 560.17$ & $-42.87 \%$ & $-23.28 \%$ & 10 \\
\hline 1849 & $\$ 125.40$ & $\$ 521.29$ & $19.89 \%$ & $-6.94 \%$ & 10 \\
\hline 1851 & $\$ 151.19$ & $\$ 632.24$ & $16.35 \%$ & $21.29 \%$ & 13 \\
\hline 1853 & $\$ 109.93$ & $\$ 854.48$ & $20.57 \%$ & $35.15 \%$ & 18 \\
\hline 1855 & $\$ 170.58$ & $\$ 574.78$ & $-27.29 \%$ & $-32.73 \%$ & 21 \\
\hline 1857 & $\$ 183.59$ & $\$ 989.07$ & $55.17 \%$ & $72.08 \%$ & 23 \\
\hline 1859 & $\$ 180.21$ & $\$ 916.74$ & $7.63 \%$ & $-7.31 \%$ & 24 \\
\hline 1861 & $\$ 166.81$ & $\$ 980.42$ & $-1.84 \%$ & $6.95 \%$ & 26 \\
\hline 1863 & $\$ 216.44$ & $\$ 884.06$ & $-7.44 \%$ & $-9.83 \%$ & 25 \\
\hline 1865 & $\$ 256.66$ & $\$ 1,145.21$ & $29.75 \%$ & $29.54 \%$ & 24 \\
\hline 1867 & $\$ 259.46$ & $\$ 1,596.86$ & $18.58 \%$ & $39.44 \%$ & 25 \\
\hline 1869 & $\$ 249.04$ & $\$ 1,457.12$ & $1.09 \%$ & $-8.75 \%$ & 26 \\
\hline & & $\$ 1,420.14$ & $-4.02 \%$ & $-2.54 \%$ & 25 \\
\hline
\end{tabular}

